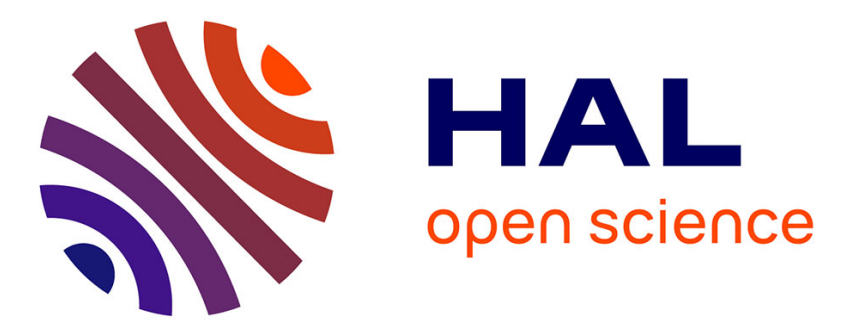

\title{
Impacts of Land Use and Climate Change on Freshwater Ecosystems in France
}

Basak Bayramoglu, Raja Chakir, Anna Lungarska

\section{To cite this version:}

Basak Bayramoglu, Raja Chakir, Anna Lungarska. Impacts of Land Use and Climate Change on Freshwater Ecosystems in France. Environmental Modeling \& Assessment, 2020, 25 (2), pp.147-172. 10.1007/s10666-019-09673-x . hal-02619251

\section{HAL Id: hal-02619251 \\ https://hal.inrae.fr/hal-02619251}

Submitted on 25 May 2020

HAL is a multi-disciplinary open access archive for the deposit and dissemination of scientific research documents, whether they are published or not. The documents may come from teaching and research institutions in France or abroad, or from public or private research centers.
L'archive ouverte pluridisciplinaire HAL, est destinée au dépôt et à la diffusion de documents scientifiques de niveau recherche, publiés ou non, émanant des établissements d'enseignement et de recherche français ou étrangers, des laboratoires publics ou privés.

\section{다)(1) $(5$}

Distributed under a Creative Commons Attribution - NonCommercial| 4.0 International 


\title{
Impacts of land use and climate change on freshwater ecosystems in France
}

\author{
Basak Bayramoglu* $\quad$ Raja Chakir $^{\dagger} \quad$ Anna Lungarska ${ }^{\ddagger}$
}

July 10, 2019

\begin{abstract}
Pressures on freshwater ecosystems are mainly human-induced and driven by land use and climate change. We develop an empirical framework to estimate the impacts of land use (agriculture, forest, pasture, urban) and climate change on freshwater biodiversity, measured by a fish-based index, in France. Our estimation results reveal that rivers in areas with more intensive agriculture and steep pasture are associated to lower freshwater biodiversity compared to forest areas. Our simulations show that climate change will exacerbate these negative impacts through land-use adaptation. We discuss how two command-and-control policies could help improving freshwater biodiversity and cope with the adverse effects of land use and climate change.
\end{abstract}

Keywords: freshwater biodiversity, fish-based index, land use, climate change, water quality, spatial panel data model.

JEL codes: C31, R14, Q22, Q53.

${ }^{*}$ Economie Publique, INRA, AgroParisTech, Université Paris-Saclay, 78850 Thiverval-Grignon, France. E-mail: Basak.Bayramoglu@inra.fr

${ }^{\dagger}$ Economie Publique, INRA, AgroParisTech, Université Paris-Saclay. E-mail: raja.chakir@inra.fr

${ }^{\ddagger}$ Corresponding author, Economie Publique, INRA, AgroParisTech, Université Paris-Saclay. E-mail: anna.lungarska@inra.fr 


\section{Introduction}

According to the Intergovernmental Science-Policy Platform on Biodiversity and Ecosystem Services report (IPBES, 2018), more than 50\% of nature's regulating and nonmaterial contributions to populations in Europe and Central Asia was lost between 1960 and 2016 1 A World Wildlife Fund report (WWF, 2016) indicates that the $81 \%$ global decline in freshwater species populations between 1970 and 2012, is more than double the declines observed in land $(38 \%)$ and marine $(36 \%)$ populations. In 2015 , surface water bodies in 22 of European Union Member States did not achieve good chemical status ${ }^{2}$ and despite the few improvements accomplished only $53 \%$ of rivers and lakes were considered to have good ecological status 3 (IPBES, 2018).

Intensification of agriculture and forestry, and urban development are the major direct drivers of loss of both biodiversity and ecosystem services in Europe (IPBES, 2018). However, the impact of climate change on biodiversity is becoming increasingly rapid, and is likely to become one of the most important drivers in the future (Millennium Ecosystem Assessment, 2005). By 2050, climate change could overtake land use change as the main cause of biodiversity decline (IPBES, 2018). This confirms the conclusions of the International Panel on Climate Change (IPCC) that water, and its availability and quality will constitute the main pressure on societies and on the environment due to climate change (Bates et al., 2008).

Climate change is likely to have both direct and indirect effects on freshwater biodiversity. The main direct impacts of climate change on freshwater biodiversity result from changes in air and water temperatures, and changes in the timing, type and intensity of precipitation (Kernan et al., 2011). Climate change also affects freshwater biodiversity indirectly through societal and economic systems such as land use and land management adaptations to climate change. It is important to take account of the effects of land use and climate change and their interactions on the freshwater biodiversity Allan, 2004, p.258). Given the importance of both land use change and climate change for influencing

\footnotetext{
${ }^{1}$ This report provides an overview of the state of biodiversity and ecosystem services, the benefits we derive from it, observed trends, future scenarios, and policy action recommendations.

${ }^{2}$ As defined by the European Union Water Framework Directive, EU WFD.

${ }^{3}$ Idem.
} 
biodiversity, including only one or other driver could lead to an inadequate assessment of their impacts (De Chazal and Rounsevell, 2009).

The objective of this paper is to evaluate the effects of both land use (agriculture, forest, pasture, urban) and climate change on freshwater biodiversity in France measured by a fish-based index (FBI) Fish are considered as a useful indicator to assess the ecological health of water bodies (Whitfield and Elliott, 2002). According to Oberdorff et al. (2002) "among potential indicators, fish assemblages are of particular interest because of their ability to integrate environmental variability at different spatial scales" (p.1720). The originality of the FBI is related to its use of multiple metrics based on both occurrence and abundance data. 5

The European Union Water Framework Directive (EU WFD) builds on two elements for the assessment of water quality, namely chemical and ecological status. Good chemical status of a water body is attained when it complies with quality standards in terms of substance concentration (established in the Directive 2008/105/EC on Environmental Quality Standards, revised in 2013). Ecological status is the assessment of the structure and functioning of aquatic ecosystems. It is determined by biological quality (plant and animal species), and hydromorphological and physico-chemical elements (macro-pollutants in particular) associated with the development of biological cycles (Eaufrance, 2015). Its measurement is subject to interpretations by Member States since each country has its specificities concerning freshwater biodiversity and ecosystems. In our study, we focus on the ecological status of water bodies.

We estimate two models: a spatial econometric land use share model, and a statistical spatial panel FBI model. The land use share model describes how land use is affected by economic, pedo-climatic and demographic factors, while the FBI model explains the spatial and temporal distribution of the FBI score by land use and pedo-climatic variables. We use data on land use shares (agriculture, pasture, forest and urban) and

\footnotetext{
${ }^{4}$ Indice Poissons Rivière (IPR) in French.

${ }^{5}$ In the paper, we use the terms freshwater biodiversity and freshwater ecological health interchangeably. We are aware that the FBI does not perfectly represent freshwater biodiversity as it only concerns a part of the fish community living in rivers and not all species, and that the different metrics that make up the index do not reflect the whole characteristics of species in terms of biological traits. Nevertheless, FBI remains an interesting index for freshwater biodiversity as it is based on several metrics. Martinho et al. (2015) have shown that indicators based on multiple metrics of fish communities successfully reflect human pressures on a Portuguese estuary.
} 
the FBI for various French rivers observed between 2001 and 2013. We use our estimation results to simulate the impacts of two climate change scenarios on the FBI: a pessimistic scenario A2, and an optimistic scenario B1 (IPCC, 2000, for the 2100 time horizon). The A2 scenario is associated with increasing greenhouse gas emissions and a continuously growing world population with limited technological progress. The B1 storyline builds on the assumption of a demographic peak in midcentury followed by a decrease and greater technological innovation both resulting in stabilized greenhouse gas concentrations in the athmosphere. The two scenarios lead to a global temperature increase between $2^{\circ}$ and $5.4^{\circ} \mathrm{C}$ (A2), and $1.1^{\circ}$ and $2.9^{\circ} \mathrm{C}$ (B1). Also, we discuss how two command-andcontrol policies could help improve freshwater biodiversity and cope with the adverse effects of land use and climate change. The two policy options considered are: (1) a standard for nitrogen fertilizer use in agriculture, and (2) a standard for livestock density on pastures.

Related literature There is a large economic literature on the effects of land use on water quality and freshwater biodiversity. However, only a very small number of studies deal with the impacts of climate change on freshwater biodiversity although the noneconomic literature on this subject is extensive. Finally, there is a small but growing economic literature which focuses on the combined impacts of land use and climate change on biodiversity and water quality.

Concerning the impacts of land use on water quality 6 , there is a vast body of work. These studies simulate the performance of specific land use policies on water quality indicators. For instance, Langpap et al. (2008) compares the relative efficiency of local land use regulations and policies that affect the returns to land use from achieving water quality improvements. Some studies in the literature focus on the effects of land use on water quality, and in some cases, take account of a specific land use class: for instance, $\mathrm{Wu}$ and Segerson (1995) and Wu et al. (2004) focus on agricultural land use, while Atasoy et al. (2006) study the case of the urban land use. Other contributions

${ }^{6}$ There are also studies that link land uses to biodiversity indicators such as forest fragmentation (Lewis et al. 2011), wildlife habitat (Martinuzzi et al. 2015), or bird populations (Beaudry et al. 2013). 
estimate the link between alternative land uses and indicators of water quality. The case of the U.S. is studied by Hascic and Wu (2006), and Keeler and Polasky (2014), the case of China by Xu et al. (2016), and the case of France by Fiquepron et al. (2013) and Abildtrup et al. (2013).

Among work that deals with the impacts of climate change on biodiversity, a recent literature review (Runting et al. 2017$)$ shows that there are a large number of ecological studies assessing the impacts of climate change on ecosystem services. According to this review, relatively few studies integrate decision making, or incorporate multiple drivers of change such as economic drivers or local drivers (land use change). This is because most studies do not use an economic framework that allows the inclusion for example, of landowners' decisions and their reaction to market drivers or global drivers such as climate change. Runting et al.'s review shows that the impact of climate change on most types of services is predominantly negative (59\% negative, $24 \%$ mixed, $4 \%$ neutral, $13 \%$ positive) but varies across services, drivers and assessment methods.

Studies that include only either land use or climate change as drivers of freshwater biodiversity are likely to assess their impacts inadequately (De Chazal and Rounsevell, 2009). These studies could suffer from either under- or over-estimation of the impacts on biodiversity. A very small number of economic studies in the literature focus on the simultaneous impacts of land use and climate change on biodiversity and water quality. The closest to our work are the studies by Ay et al. (2014) and Fezzi et al. (2015). Ay et al. (2014) propose a modeling framework that integrates simultaneously the direct impacts of land use and climate change on the abundance of common birds as an indicator of biodiversity, as well as the indirect impacts through climate change effects on land use in France. They study the impacts of five different scenarios which differ in the way they account for land use impacts and in the role played by economic returns, public policies and climate on land use. Their results show that in France bird community dynamics are projected to be more heavily impacted by climate change than by land use. This result is in line with other local scale evidence (Martin et al., 2013) but contradicts global studies which suggest that land use compared to climate change will dominate biodiversity dynamics (Pereira et al., 2010). Fezzi et al. (2015) propose 
an integrated framework linking a spatially explicit econometric model of agricultural production to a statistical model of river water quality in the U.K. They examine how adaptation to climate change in agriculture is expected to affect water quality. They simulate how a spatially targeted afforestation regulation affects water quality when accounting for the effect of climate change on land use adaptation. Their results show that climate adaptation in the farming sector will generate fundamental changes to river water quality. In some areas, policies that encourage adaptation are expected to conflict with existing regulations aimed at improving freshwater ecosystems.

This paper makes several contributions to the literature. First, we study freshwater biodiversity (an indicator of ecological water quality) unlike the extensive literature on chemical water quality. Secondly, we take into account multiple land uses (including agriculture, forest, pasture and urban land uses) unlike the literature focusing either on agriculture or on urban land use. Third, we distinguish the impacts of intensive and extensive land management in agriculture and pasture on freshwater biodiversity. Fourth, we explicitly consider the spatial dimension by estimating a spatial panel model to take account of individual heterogeneity as well as spatial autocorrelation of freshwater biodiversity. Finally, and more importantly, we estimate the combined effects of land use and climate, and we simulate the impacts of climate change scenarios and public policies to improve freshwater biodiversity.

This study addresses the following questions: (i) How does land use and climate change affect freshwater biodiversity in France? (ii) How could a public policy regulation such as standards for nitrogen fertilizer use in agriculture or livestock density on pastures, improve freshwater biodiversity? (iii) Would these policy options resolve the adverse effects of land use and climate change on freshwater biodiversity?

The remainder of the paper is organized as follows. Section 2 provides background information on freshwater biodiversity in France; section 3 presents the empirical model; section 4 describes the data and section 5 presents the estimation and simulation results. Section 6 concludes by summarizing our main results. 


\section{Freshwater biodiversity in France}

In this section, we discuss first the status of water quality in France and the related regulation in the European Union (EU), and second the FBI used in our study to indicate freshwater biodiversity.

\subsection{Ecological status of water in France and European regulation}

In the IUCN 7 - International Union for Conservation of Nature - Red List of Threatened Species published in 2012, France is ranked fifth in the world for hosting the largest number of endangered plant and animal species. This list indicates that Spanish toothcarp (Aphanius iberus) and Valencia toothcarp (Valencia hispanica) have become extinct, and sturgeon (Acipenser sturio), European eel (Anguilla anguilla), Chabot du Lez (Cottus petiti) and Rhone streber (Zingel asper) are critically endangered in France (UICN France, MNHN, SFI, ONEMA, 2010). The degradation of freshwater biodiversity is due to a decline in the quality and quantity of water, and changes to the distribution and structure of aquatic biota in some rivers in France (Oberdorff et al., 2002). French freshwater fish populations have suffered from the degradation and destruction of natural environments as well as pollution.

France has been unable to comply with the objective of the EU WFD to achieve good or very good surface water quality by 2015 for $60 \%$ of its national water resources. In terms of chemical status, only $48.2 \%$ of French surface water resources were of acceptable quality in 2013. In terms of ecological status, only $43.4 \%$ of surface water resources were deemed to be good or very good quality (Onema/OIEau, 2015). Since 2015, two further deadlines for meeting the environmental objectives in the EU WFD were issued - 2021, and 2027 the final date for compliance ${ }^{8}$

\section{$2.2 \quad$ Fish-based index}

Fish are considered a useful indicator to assess the ecological health of water bodies (Whitfield and Elliott, 2002). Fish-based indices are a method to assess water

\footnotetext{
${ }^{7}$ http://www.iucn.org/

${ }^{8}$ http://ec.europa.eu/environment/water/water-framework/info/timetable_en.htm.
} 
quality status based on metrics derived from structure and function of fish assemblages. The index proposed by Oberdorff et al. (2002) was explicitly designed to evaluate for France the respect of the WFD. It uses multiple metrics based on both occurrence data and abundance data. The metrics based on abundance data account for regional and local environmental factors (Oberdorff et al., 2002). A FBI has been built for France for a large number of well-defined sites evenly distributed across all available types of rivers monitored between 2001 and 2013.

The FBI employs seven metrics to calculate a site's current index score which is compared to a reference (in the absence of stress) situation score. The value of the index includes the sum of the deviations from the reference situation of seven metrics: (1) Total number of species; (2) Number of lithophilic species (which require clean gravel substrates for reproductive success); (3) Number of rheophilic species (which inhabit lotic areas); (4) Total density of individuals (which measures individual abundance); (5) Density of tolerant species (species with large water quality and habitat flexibility); (6) Density of invertivorous species (species that feed mainly on invertebrates); (7) Density of omnivorous species (species that can digest considerable amounts of both plants and animals).

The closer the fish population to the reference situation, the lower the value of the index. The index varies from 0 (meaning the reference situation prevails) to infinity. In practice, in the most altered stations the FBI rarely exceeds 150 . Defined by FBI scores, Oberdorff et al. (2002) identify five classes of water quality for river basins: very good $(\leq 7)$; good (] $7-16])$; mediocre (] $16-25])$; bad (] $25-36])$; very bad $(>36)$. This classification is used also by the decision makers (SOeS, 2012). Figures 1 and 2 respectively depict the evolution and spatial distribution of the FBI scores for French hydrographic sectors 9

SOeS (2012) describes the evolution of the FBI index over the period 2001 to 2010 (see figure 11). The report notes that the index was mostly relatively constant over the period considered with the exception of 2003 which experienced exceptionally high

\footnotetext{
${ }^{9} \mathrm{~A}$ hydrographic sector represents a smaller area than a hydrographic region. There are 187 hydrographic sectors in metropolitan France. This geographical scale has been used in other studies of water quality (Lungarska and Jayet, 2018).
} 


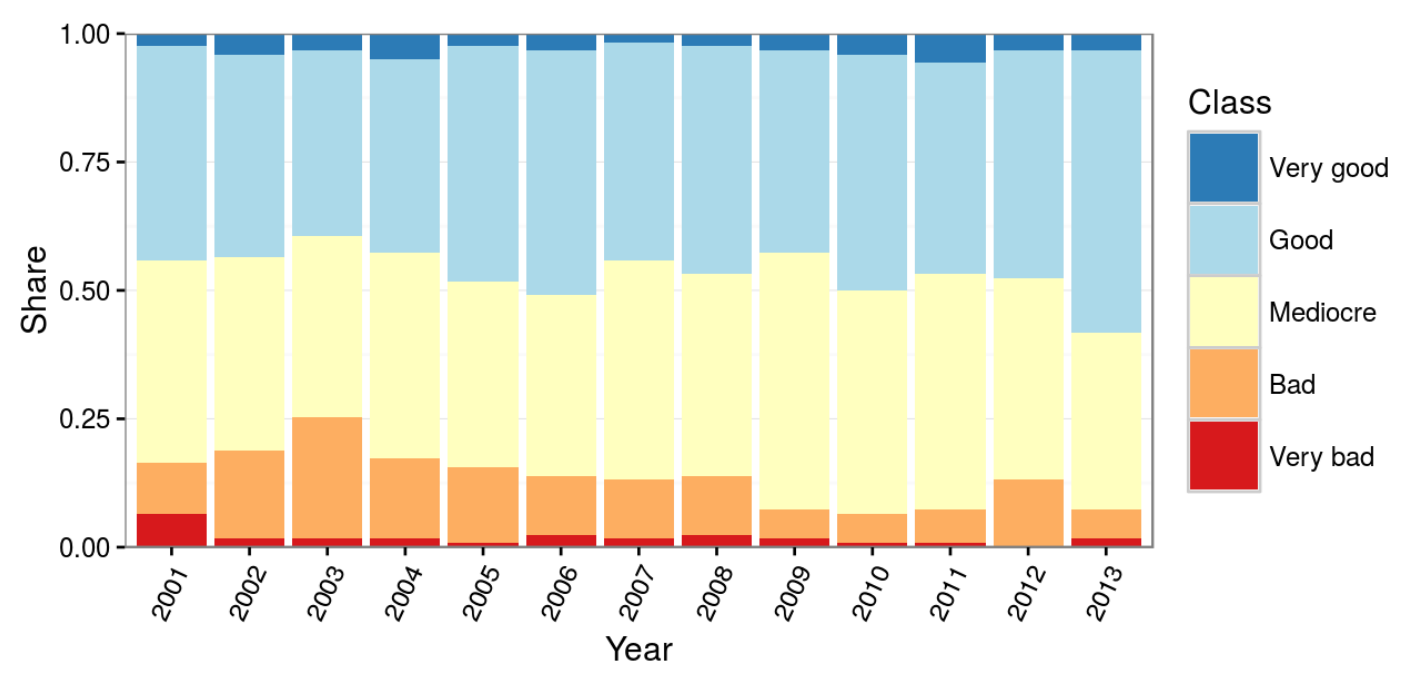

Figure 1: FBI scores for hydrographic sectors, time variation (2001 - 2013)

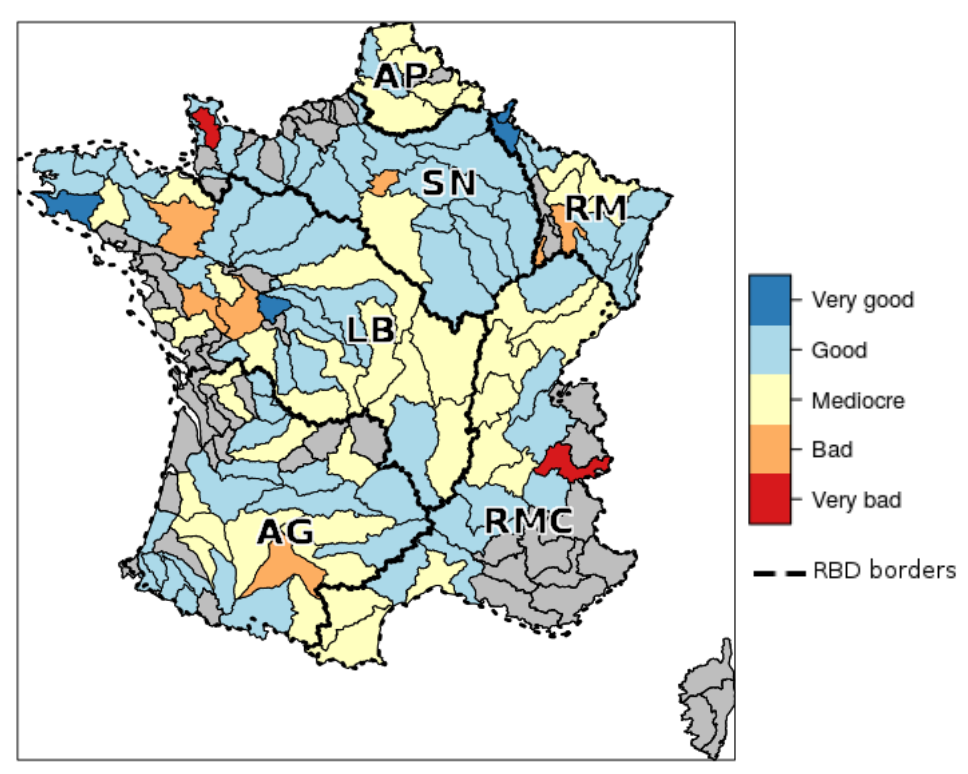

Figure 2: FBI scores for hydrographic sectors, space variation in 2013. French River Basin Districts (RBD) - Adour-Garonne (AG), ArtoisPicardie (AP), Loire-Bretagne (LB), Rhône-Méditerranée-Corse (RMC), Rhin-Meuse (RM), and Seine-Normandie (SN). 
temperatures and particular hydrological conditions. It highlights that slightly more than half of the monitoring points recorded good or very good quality. However, to meet the EU WFD water quality standards will require additional efforts. SOeS (2012) proposes some explanations for the spatial heterogeneity of the FBI index for the six river basin districts $\left(\mathrm{RBD}^{10}\right.$, as defined in the EU WFD, presented on figure 2) in France. The Artois-Picardie RBD which is very densely populated appears to be the district with the highest number of points with low ecological quality. This is due to human-induced pressures from industrialization and intensive agriculture. The Seine-Normandie RBD is in the best position. The water quality is worst in the center regions of Picardie and Région Parisienne due to urban development and intensive agriculture. Intensive agriculture especially livestock production is at the origin also of the degradation of river basin quality in Loire-Bretagne. In the Rhin-Meuse RBD, the FBI score indicates that regions with more forest land have better water quality. The Adour-Garonne RBD is affected negatively by hydro-electricity and intensive agricultural production. The Rhône-Méditerranée RBD is affected by urban development, dam construction, and hydro-electricity production. In sum, downstream points, and non-coastal water bodies suffer more from human-induced disturbances.

\section{The empirical models}

In our study, we investigate the effects of land use and climate change on freshwater biodiversity measured by the FBI index. We take also account of the impacts of climate change on land use. These relationships are summarized in Equations 1 and 2 where FBI is presented as a function $(f)$ of land use $(L U)$, climate $(C L)$, and soil characteristic ${ }^{11}$ $(S Q)$, while land use is a function $(h)$ of land rents $(\mathbf{R}(C L))$, which depend on climate among others, and of other physical parameters $(\mathbf{P})$. In the FBI model, we use the predicted land use shares derived from the land use model $(\widehat{L U})$. We develop these

\footnotetext{
${ }^{10}$ France is divided into six RBD: Rhône-Méditerranée-Corse, Rhin-Meuse, Loire-Bretagne, SeineNormandie, Adour-Garonne and Artois-Picardie. They correspond respectively to five large rivers (Rhône, Rhin, Loire, Seine et Garonne), and the Somme river. See also figure 6 in the appendix.

${ }^{11}$ When modeling nonpoint source pollution (as the one from agriculture) it is important to account for the pollutant fate and transport function Shortle and Horan (2002). In order to approximate this function, we control for the soil characteristics in the FBI model.
} 
relationships further in sections 3.1 and 3.2 .

$$
\text { Land use model: } L U=h(\mathbf{R}(C L), \mathbf{P})
$$

$$
\text { FBI model: } F B I=f(\widehat{L U}, C L, S Q)
$$

Thus, we estimate two models: i) a spatial panel model explaining freshwater biodiversity measured by the FBI index, and ii) a spatial land use share model.

\subsection{Land use share model}

We estimate an econometric land use share model with cross-section data. Our econometric model is based on econometric land use models estimated on aggregate data such as Lichtenberg (1989); Stavins and Jaffe (1990); Plantinga (1996); Miller and Plantinga (1999) for the U.S. case, and Chakir and Le Gallo (2013); Ay et al. (2017); Chakir and Lungarska (2017) among others for the case of France.

The land use share $S_{g l}$ is computed as the share of the areas in grid $g(\forall g=1, \ldots, G)$ with land use $l(\forall l=1, \ldots, L)$. These shares are written as:

$$
S_{g l}=\frac{\exp \left(\mathbf{R}_{g} \boldsymbol{\beta}_{l}^{R}+\mathbf{P}_{g} \boldsymbol{\beta}_{l}^{P}\right)}{\sum_{l=1}^{L} \exp \left(\mathbf{R}_{g} \boldsymbol{\beta}_{l}^{R}+\mathbf{P}_{g} \boldsymbol{\beta}_{l}^{P}\right)},
$$

where $\mathbf{R}_{g}$ is a vector of land use rents, $\boldsymbol{\beta}_{l}^{R}$ is the associated vector of the parameters to be estimated; $\mathbf{P}_{g}$ is a vector of physical characteristics and $\boldsymbol{\beta}_{l}^{P}$ is the associated vector of the parameters to be estimated.

Linearizing the model in Equation 3 allows us to estimate Equation 4 with a reference land use, $L$.

$$
\tilde{S}_{g l}=\ln \left(S_{g l} / S_{g L}\right)=\mathbf{R}_{g} \boldsymbol{\beta}_{l}^{R}+\mathbf{P}_{g} \boldsymbol{\beta}_{l}^{P}+u_{l g}, \forall g=1, \ldots, G, \forall l=1, \ldots, L-1
$$

We model spatial autocorrelation explicitly by employing the spatial Durbin error model specification (SDEM, LeSage and Pace, 2009). This model specification allows 
us to take account of the spatial autocorrelation in error terms as well as dependence between land use shares and the neighboring explanatory variables. Two neighbor structures are included in order to represent the scale at which the explanatory variables are originally available (Equation 5).

$$
\tilde{S}_{g l}=\mathbf{R}_{g} \boldsymbol{\beta}_{l}^{R}+\mathbf{P}_{g} \boldsymbol{\beta}_{l}^{P}+W_{L}^{\prime}\left(\mathbf{R}_{g^{\prime}} \boldsymbol{\beta}_{l}^{R^{\prime}}+\mathbf{P}_{g^{\prime}} \boldsymbol{\beta}_{l}^{P^{\prime}}\right)+W_{L}^{\prime \prime} \mathbf{R}_{j^{\prime}} \boldsymbol{\beta}_{l}^{R^{\prime \prime}}+u_{l g}
$$

The error term $u_{l g}=\lambda W_{L}^{\prime} \epsilon+\varepsilon$ corrects for spatial autocorrelation of the error terms through the $\lambda$ coefficient given the spatial weight matrix $W_{L}^{\prime}$ (obtained here via a contiguity rule "queen" for the grid cells). The $W_{L}^{\prime}$ matrix is used to weight fine-scale rent variables $\left(\mathbf{R}_{g^{\prime}}\right)$, the physical parameters $\left(\mathbf{P}_{g^{\prime}}\right)$, and the grid level error terms. The $W_{L}^{\prime \prime}$ matrix is applied to the regional scale land rents $\left(\mathbf{R}_{j^{\prime}}\right)$. Both matrices are defined following the "queen" contiguity rule.

\section{$3.2 \quad$ FBI model}

We estimate a model explaining the observed FBI score as a function of land uses (agriculture, forest, pasture, urban and other), land quality and climate. The spatial resolution chosen for the FBI model, is the hydrographic sector which is the most appropriate for observing fish populations in rivers. A hydrographic sector is a subdivision of the river basin districts ("bassin versant" in French) established by the EU WFD.

The double dimension of the panel data provides additional information in relation to cross-section data. It allows us to control the presence of individual effects in the model through random effects (RE). This structure of the error term makes it possible to account for the heterogeneity between hydrographic sectors. Moreover, considering a random-error specification rather than a fixed effects specification allows us to estimate effects for time invariant variables such as soil quality in our case.

Using spatial tools, we control for any spatially correlated unobserved factors that might influence water quality by estimating a spatial error model (SEM). The SEM posits that the error terms of a given location depend on the error terms of neighbors. This assumption can be justified on two grounds. First, there may be data measurement errors involving the water quality boundary differing from the boundaries of the hydrographic 
sectors used for the measurement. This is quite plausible in our case since a river can cross several hydrographic sectors. Second, omitted variables such as fish migration or any local pollution which is not directly related to land use could be spatially correlated.

We assume that $F B I_{i t}$ in location $i$ at time $t(i=1, \ldots, N$ and $t=1, \ldots, T)$ is generated according to the following model:

$$
\begin{aligned}
\log \left(F B I_{i t}\right) & =\widehat{L U}_{i t} \alpha+C L_{i t} \beta+S Q_{i} \gamma+v_{i t}, \\
v_{i t} & =\mu_{i}+\varepsilon_{i t}, \\
\varepsilon_{i t} & =\lambda W_{F} \varepsilon_{i t}+u_{i t},
\end{aligned}
$$

where for the $i$ th hydrographic sector at time $t, \widehat{L U}_{i t}$ is a vector of predicted land use shares, $C L_{i t}$ is a vector of climate variables, $S Q_{i}$ is a vector of soil quality variables, $\mu_{i}$ is the individual effect of location $i$ assumed to be $\operatorname{IID}\left(0, \sigma_{\mu}^{2}\right), \varepsilon_{i t}$ is the autoregressive spatial error term, $W_{F}$ is the spatial weight matrix and $u_{i t}$ is an IID error term with zero mean and variance $\sigma_{u}^{2}$.

A variety of weighting schemes is possible; the choice depends on the process being studied, the data and the estimated model. We first consider three weight matrices: the contiguity matrix, the Delauney triangulation matrix and the upstream-downstream matrix. In all three cases, the matrices are row-normalized. Given the close results obtained for each of these neighboring structures, we opt for a combined contiguityupstream matrix as depicted in figure 3. In this neighbor structure, contiguous neighbors located upstream have a greater weight in the weight matrix $W_{F}$. Some hydrographic sectors are hydrologically independent and have no upstream-downstream neighbors (mostly in coastal zones, see e.g. Brittany peninsula). However, main rivers cross multiple hydrographic sectors and are thus the vector of upstream-downstream processes. These processes are important for fish migration and for pollution spillovers.

\section{Data description}

In this section, we describe the datasets used for the land use share and the FBI models. Summary statistics of the data used in the land use share model are described in table 


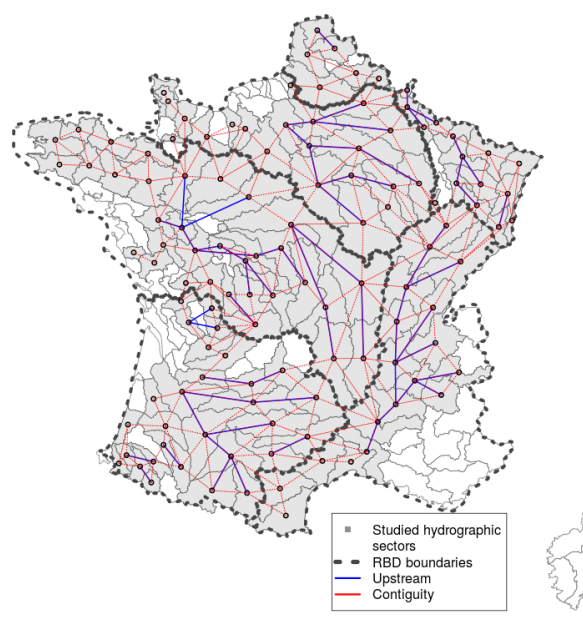

Figure 3: Neighbor relations following a contiguity-upstream rule

300

15 in appendix D, A summary of the data used in the FBI model is also provided in table 1 .

\subsection{Land use share model}

Land use shares The land use share model is estimated for year 2000 using data derived from the Corine Land Cover (CLC) database and represented by aggregated land use classes for agriculture, pasture, forest, urban and other uses at a regular 8 $\mathrm{km} \times 8 \mathrm{~km}$ grid scale ${ }^{12}$ CLC is available also for the years 2006 and 2012. However, estimates for agricultural rent are available only for 2002, and forest rents are evaluated from 2006 onward. For these reasons, we can estimate land use shares only as a crosssection model. We decided to base our estimations on 2000 data which is the year closest to our agricultural land rent proxy.

For the area of metropolitan France, we observe approximately 9,000 grid cells. Crops and pastures are modeled together because of lack of dedicated land rent proxies for each use. However, we can distinguish the shares for the two uses (see more details in Construction of agricultural and pasture land use classifications in section 4.2.

\footnotetext{
${ }^{12}$ The aggregation rules are provided in table 14 in Appendix $\mathrm{D}$
} 
Agricultural and forestry rents As in Lungarska and Chakir (2018), we proxy agricultural and forestry rents by the results of two sector-specific mathematical programming models. First, the agricultural supply-side model AROPAj (Jayet et al. 2015) provides estimates for land shadow prices under current and future climate scenarios (Leclère et al., 2013). This model represents agricultural systems and accounts for different autonomous adaptations available to farmers. Some of its features important for this study are: i) endogenous choice of mineral fertilizer quantities, ii) land switch between different crops and pastures, and iii) endogenous choice of animal husbandry regime (feed or pasture). Second, the partial equilibrium French forestry sector model (FFSM++, Caurla et al., 2013, Lobianco et al., 2016) optimizes forestry management and evaluates expected revenues for the sector. Its estimates under climate change scenarios integrate a possible switch between tree species as adaptation by forest managers. These two rent variables allow us to account for climate evolution following two climate change scenarios (A2 and B1).

Demography Land rents in the case of urban use are approximated by demographic information on population density and revenues 13 When we simulate the effects of the climate change scenarios, we introduce predictions about demographic evolution in France 14

Soil quality and topography In order to refine our land use predictions, we introduce information on soil quality measured by texture classes (Panagos et al., 2012). For instance, variable texture (cl. 1 ) represents the share of soil texture class 1 in the $8 \times 8$ $\mathrm{km}$ grid cell. In our model, we use this texture class as the reference since it describes the worst soil quality. We control also for the average slope (derived from GTOPO3 ${ }^{15}$ data) in the grid cell and in neighboring cells.

\footnotetext{
${ }^{13}$ Provided by the French statistical institute, INSEE.

${ }^{14}$ Up to 2040 we apply French statistical institutes's (INSEE) predictions at the French département level and then at the national level up to 2060 (http://www.insee.fr/fr/themes/detail.asp?reg_id= 0\&ref_id=donnees-carroyees\&page=donnees-detaillees/donnees-carroyees/donnees_carroyees_ diffusion.htm ). Afterwards, we downscale and apply predictions from CIESIN for Western Europe (Center for International Earth Science Information Network, 2002).

${ }^{15}$ For more information: https://1ta.cr.usgs.gov/GT0P030
} 
Accounting for climate change Climate change has a direct impact on agricultural and forest land uses. We use the results from the aforementioned sector-specific models AROPAj and FFSM++ because both account for the effects of climate change on their respective land based sectors. Furthermore, these models allow for some autonomous adaptation to climate change. We build on the results for climate change in Leclère et al. (2013) for agriculture and of Lobianco et al. (2016) for forestry. The predictions from climate change scenarios A2 and B1 indicate an increase in the profitability of French agriculture and a decrease in forestry. The results for land use indicate that we can expect agricultural land use to expand at the expense of forest land use (Lungarska and Chakir, 2018). More information on the climate change scenarios is provided in section 5.2 .1

\subsection{FBI model}

Land use share estimates Since the FBI model is based on panel data and the land use share model is estimated for 2000 (as mentioned previously), we use information from CLC for 2006 and 2012 to derive annual evolution rates for the different land use classes in order to obtain land use share estimations for years 2001 to 2013 (the time period covered by the FBI model). For instance, we calculate the evolution of the urban area between two CLC observations in 2000 and 2006. Thus, we can deduce the annual rate of increase or decrease for this land use and this period. We then apply this evolution rate to the estimations of the land use share model.

The same technique is applied to all land use share estimations employed in the FBI model. We use these inferred values rather than observed values in order to avoid bias when simulating the effects of climate change and public policy (section 5.2.1).

\section{Construction of agricultural and pasture land use classifications Agriculture} and pasture land uses have different environmental impacts depending on the intensity of the land use and the slope of the plots. We account for slope since it matters for leaching and soil erosion which have an impact on water pollution. To capture the effects of land management on freshwater biodiversity, we distinguish four classes for each of these two land uses. The distinction is made at the scale of the regular grid of the land use 


\begin{tabular}{|c|c|c|c|}
\hline Variable & Definition & Unit & Year \\
\hline FBI & $\begin{array}{l}\text { FBI score } \\
\text { Scale: point; aggregated at the hydrographic sector } \\
\text { level } \\
\text { Source: Oberdorff et al. (2002), The French Na- } \\
\text { tional Agency for Water and Aquatic Environment, } \\
\text { ONEMA. }\end{array}$ & - & $2001, \ldots, 2013$ \\
\hline $\begin{array}{l}\text { Weather } \\
\bullet \mathrm{T} \\
\bullet \text { rain_cv }\end{array}$ & $\begin{array}{l}\text { Annual average temperature in the hydrographic sec- } \\
\text { tor } \\
\text { Coefficient of variation in monthly precipitation } \\
\text { Scale: } 8 \times 8 \mathrm{~km} \text { grid; aggregated at the hydrographic } \\
\text { sector level } \\
\text { Source: Météo France, ARPEGE (Pagé et al. } 2010 \text {, } \\
\text { Pagé and Terray, 2010). }\end{array}$ & ${ }^{\circ} \mathrm{C}$ & $\begin{array}{l}1990, \quad \ldots, 2013 \\
2100 \\
1990, \ldots, 2013 \\
2100\end{array}$ \\
\hline TXT1, .., TXT4 & $\begin{array}{l}\text { Share of the texture class in the hydrographic sector } \\
\text { Scale: } 1: 1,000,000 ; \text { aggregated at the hydrographic } \\
\text { sector level } \\
\text { Source: Panagos et al. }(2012) \text {, European Union Joint } \\
\text { Research Center, JRC. }\end{array}$ & $\%$ & Invariant \\
\hline Slope & $\begin{array}{l}\text { Scale: } 30 \text { arc sec; averaged at a regular grid level } \\
\text { Source: GTOPO30, https://lta.cr.usgs.gov/ } \\
\text { GTOP030 }\end{array}$ & $\%$ & Invariant \\
\hline $\begin{array}{l}\text { Land use } \\
\text { - agr } \\
\quad \text { - agr1 } \\
\text { - agr2 } \\
\text { - agr3 } \\
\text { - agr4 } \\
\text { - pst } \\
\text { - pst1 } \\
\text { - pst2 } \\
\text { - pst3 } \\
\text { - pst4 } \\
\text { - for } \\
\text { - urb } \\
\text { - oth }\end{array}$ & $\begin{array}{l}\text { Share of each land use in the hydographic sector } \\
\text { Agriculture share } \\
\text { low slope, low intensity } \\
\text { low slope, high intensity } \\
\text { high slope, low intensity } \\
\text { high slope, high intensity } \\
\text { Pasture share } \\
\text { low slope, low intensity } \\
\text { low slope, high intensity } \\
\text { high slope, low intensity } \\
\text { high slope, high intensity } \\
\text { Forest share } \\
\text { Urban share } \\
\text { Other } \\
\text { Scale: } 1 \text { ha; aggregated at the hydrographic sector } \\
\text { level } \\
\text { Source: Corine Land Cover. }\end{array}$ & $\%$ & $\begin{array}{l}\text { Interpollation } \\
\text { using data for } \\
2000,2006 \text {, and } \\
2012\end{array}$ \\
\hline Intensity & $\begin{array}{l}\text { Nitrogen use and livestock density } \\
\text { Scale: Spatialized at } 8 \times 8 \mathrm{~km} \text { regular grid scale } \\
\text { Source: AROPAj, (Jayet et al., 2015) }\end{array}$ & $\begin{array}{l}\mathrm{kg} N / \mathrm{ha} \\
\text { livestock } \\
\text { units/ha }\end{array}$ & 2002 \\
\hline
\end{tabular}

Table 1: Data description of the FBI model

terms of agriculture and forestry, and their exclusion makes sense if we exclude outliers.

The summary statistics presented in table 1 show that the average FBI score in the sample is 17.46 , meaning that the ecological quality of water is poor on average. 

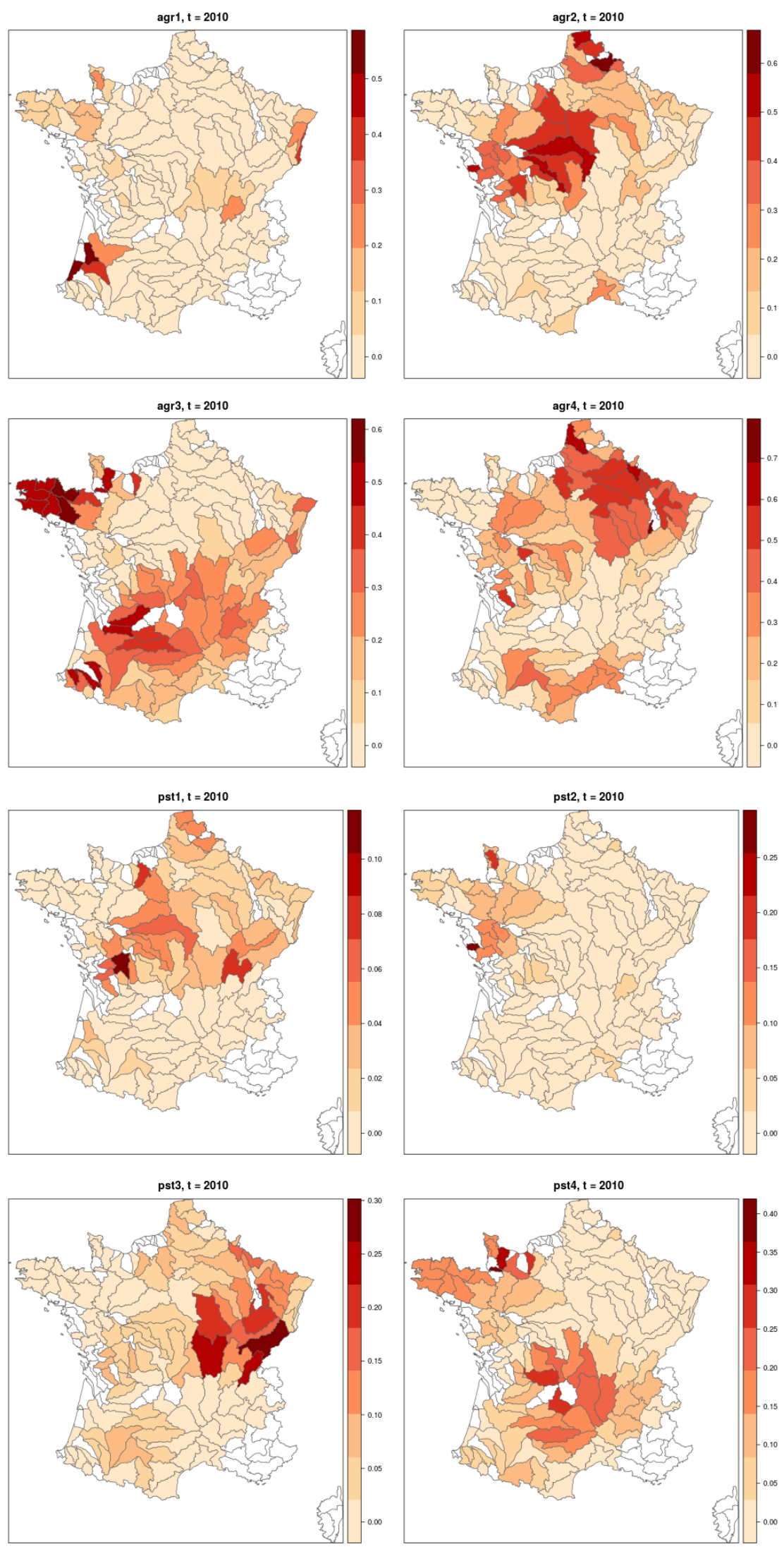

Figure 4: Land shares for the four agricultural and four pasture classes 
Agricultural land (crops+pasture) accounts for the largest area in the sample (65\%), followed by forests (25\%), urban land (5\%), and other land uses (4\%).

\begin{tabular}{lrrrrrrr}
\hline Variable & Min. & 1st Qu. & Median & Mean & 3rd Qu. & Max. & St. Dev. \\
\hline FBI & 3.373 & 12.68 & 16.56 & 17.46 & 21.18 & 63.44 & 7.04 \\
Texture (cl. 2) & 0 & 0.2233 & 0.4066 & 0.4506 & 0.7212 & 0.9595 & 0.26 \\
Texture (cl. 3) & 0 & 0.0381 & 0.1964 & 0.263 & 0.475 & 0.8639 & 0.25 \\
Texture (cl. 4) & 0 & 0 & 0.0495 & 0.1181 & 0.1652 & 0.727 & 0.16 \\
rain_cv & 18.8 & 50.33 & 65.07 & 67.88 & 81.99 & 162.8 & 23.651 \\
T & 3.903 & 10.48 & 11.3 & 11.27 & 12.19 & 15.56 & 1.507 \\
agr1 & 0 & 0 & 0 & 0.0397 & 0.0330 & 0.5582 & 0.094 \\
agr2 & 0 & 0 & 0.0268 & 0.1225 & 0.2119 & 0.6237 & 0.165 \\
agr3 & 0 & 0 & 0.1267 & 0.1633 & 0.2784 & 0.5874 & 0.174 \\
agr4 & 0 & 0.0005 & 0.1488 & 0.1935 & 0.3321 & 0.7526 & 0.193 \\
pst1 & 0 & 0 & 0.0047 & 0.0151 & 0.0235 & 0.1103 & 0.021 \\
pst2 & 0 & 0 & 0 & 0.0165 & 0.0119 & 0.2739 & 0.039 \\
pst3 & 0 & 0.0008 & 0.0259 & 0.0452 & 0.0665 & 0.2868 & 0.06 \\
pst4 & 0 & 0 & 0.0306 & 0.0683 & 0.1134 & 0.3922 & 0.085 \\
urb & 0.0042 & 0.0184 & 0.0266 & 0.04296 & 0.0442 & 0.4422 & 0.053 \\
oth & 0.0029 & 0.0149 & 0.0281 & 0.05758 & 0.0672 & 0.4945 & 0.082 \\
\hline
\end{tabular}

Table 2: Descriptive statistics of the variables in the FBI model

\section{$5 \quad$ Estimation and simulation results}

Section 5.1 presents the econometric results from the estimations of the impacts of land use on FBI. Section 5.2 presents the simulation results of the climate change scenarios and two command-and-control policies aimed at improving freshwater biodiversity in France.

\subsection{Econometric estimation results}

To compare estimations and to evaluate the gains from allowing for both spatial autocorrelation and individual heterogeneity, we consider the following estimators for the

FBI model:

1. Pooled ordinary least squares (OLS) which ignores individual heterogeneity and spatial autocorrelation; 
2. RE (random effects) estimator which accounts for random individual effects but ignores spatial autocorrelation;

3. SEM which takes account of the autoregressive spatial error autocorrelation but ignores individual heterogeneity;

4. SEM-RE estimator which accounts for both spatial error autocorrelation and random individual heterogeneity.

In order to take account explicitly of spatial heterogeneity and possible differences in public policies, we also include fixed effects (FE) for river basin districts (RBD).

The detailed results for the estimated models are provided in appendices $\mathrm{B}$ and $\mathrm{C}$ (tables 8 to 13). Tables 8 to 10 present the results for the OLS, RE, SEM and SEM-RE models for the three weight matrices: contiguity, contiguity-upstream and triangulation. Tables 11 to 13 present the results for the same models with added RBD FE to account for any individual specific characteristics of local water agencies.

We start by estimating the pooled OLS model and testing three weight matrix specifications: contiguity, triangulation and upstream. The Moran's I statistic significant at the $1 \%$ confidence level for the two weight matrices, contiguity and triangulation, and is not significant for the upstream weight matrix (see tables 6 and 7 ). Thus, the FBI scores are subject to potential spatial autocorrelation. In several cases, elements of the upstream weight matrix have no neighbors. This might explain why the Moran's I coefficient in this spatial setting is not significant. Upstream relations are important for hydrology. Hence, we combine information on upstream relations with the contiguity matrix and define a new weight matrix called contiguity-upstream which assigns greater importance to neighbors located upstream. The results in tables 6 and 7 show that the Moran's $I$ statistics are mostly higher for the contiguity-upstream matrix than for the contiguity matrix.

We next estimate the SEM model which has a significant spatial autocorrelation coefficient ranging from $\rho=0.194$ to $\rho=0.38$ for the three weight matrices and with and without the RBD FE specifications (tables 8 to 13 ). These results indicate that ignoring spatial autocorrelation could lead to inconsistent estimation. 
The RE model results show that the fraction of the variance due to the differences across hydrographic sectors $\phi$ is significant for all specifications (with and without RBD FE). When we take account of both spatial autocorrelation and individual heterogeneity, $\rho$ and $\phi$ remain significant for all the specifications (with the three weight matrices, and with and without RBD fixed effects). Since most of the results are stable for all the specifications, we focus in what follows on interpreting the results of the SEM-RE model based on the contiguity-upstream weight matrix presented in appendix $\mathrm{C}$ (table 12).

The results of this model show that most of the coefficients associated to agricultural land, urban land and pasture are statistically significant and positive. Since forest is our reference land use, this result means that the marginal effects of agricultural, pasture and urban land uses on FBI are larger than the marginal effect of forest land on FBI. Recall here that the higher the FBI score, the greater is the difference between the reference situation (absence of stress) and the observed fish population.

In order to compare the relative impacts of alternative land uses on the FBI score, we calculate the elasticities of the FBI index with respect to each land use class at the mean land uses value (table 3). These elasticities could be interpreted as follows: an increase of $1 \%$ in the land use class agr 2 will increase the FBI score by $0.158 \%$. The results show that the land use class that has the largest effect on the FBI score is low slope-high intensity crops (agr2), followed by high slope-high intensity pasture (pst4), high slopehigh intensity crops (agr 4), high slope-low intensity pasture (pst3), and urban land use. Our results are in line with those in Ministère de l'environnement (2017) which mentions that water quality in France shows an overall marked increase in agricultural and livestock pollution due mainly to nitrates and pesticides, and a decrease in industrial, domestic and urban pollution since the creation 50 years ago of water agencies. Our results for the adverse impacts in France of pasture located on steep slopes on nitrate emissions from manure confirm those documented in Peyraud et al. (2014). The results for urban use are in line also with the findings in Langpap et al. (2008) for four U.S. states, and those in Fiquepron et al. (2013) for France.

The effects of soil, temperature and rain variability on the FBI are not significant. Some river basin districts FE are significant, and year 2003 FE is significantly positive. 
This indicates that the exceptional drought that occurred in 2003 reduced freshwater biodiversity. This suggests some intuitions concerning the potential impacts of climate change on FBI.

\begin{tabular}{lllll}
\hline Variable & $\begin{array}{l}\text { SEM-RE } \\
\text { coefficient }\end{array}$ & $\begin{array}{l}\text { Mean land } \\
\text { use share }\end{array}$ & $\begin{array}{l}\text { FBI elasticity } \\
\text { wr to land use }\end{array}$ \\
\hline agr2 & $1.293^{* *}$ & 0.123 & $0.158^{* *}$ & LS-HI \\
pst4 & $1.522^{* *}$ & 0.068 & $0.104^{* *}$ & HS-HI \\
agr4 & $0.510^{*}$ & 0.194 & $0.099^{*}$ & HS-HI \\
pst3 & $2.145^{* *}$ & 0.045 & $0.097^{* *}$ & HS-LI \\
urb00 & $2.025^{* * *}$ & 0.043 & $0.087^{* * *}$ & \\
pst2 & $2.362^{*}$ & 0.017 & $0.039^{*}$ & LS-HI \\
agr1 & $0.896^{*}$ & 0.040 & $0.036^{*}$ & LS-LI \\
agr3 & 0.283 & 0.163 & 0.046 & HS-LI \\
pst1 & -2.158 & 0.015 & -0.033 & LS-LI \\
oth00 & 0.272 & 0.058 & 0.016 & \\
\hline
\end{tabular}

LS: low slope; HS: high slope; LI: low intensity; HI: high intensity. Note: $\quad{ }^{*} \mathrm{p}<0.1 ;{ }^{* *} \mathrm{p}<0.05 ;{ }^{* * *} \mathrm{p}<0.01$

Table 3: Elasticities of the FBI score with respect to the different land use classes calculated at the mean value of land uses

Overall, the results show that the marginal effects of agricultural, pasture and urban land uses on FBI are larger than the marginal effect of forest land on FBI. This is as expected since the main factors that affect the abundance and diversity of aquatic life have been identified as nutrient loading, toxic pollution and habitat alteration (Hascic and $\mathrm{Wu}, 2006$ ).

\subsection{Simulation of climate change and public policies}

In what follows, we first describe the simulated climate change and public policy scenarios and then present the simulation results.

\subsubsection{Simulated scenarios}

Climate change scenario simulations We simulate the effects of land use and land use adaptation to climate change on freshwater biodiversity. We consider two IPCC scenarios: an optimistic B1 scenario, and a pessimistic A2 scenario associated to a greater increase in temperature (IPCC, 2000, for the 2100 time horizon). An important differ- 
ence between the two climate change scenarios is the hypothesis concerning demography. The A2 scenario supposes a positive demographic evolution in France, while the B1 scenario is based on an assumption of a more stable and even decreasing population. These diverging hypothesis explain the difference in the predicted urban area and the resulting difference in agricultural area whose expansion is more limited in the A2 scenario compared to B1. In terms of land management, both climate change scenarios are associated to increasing quantities of nitrogen fertilizer use (Leclère et al., 2013).

We build on the results in Lungarska and Chakir (2018) on the impact of climate change on land use. Climate change affects the land rents of different land-based economic activities such as agriculture, pasture and forestry. Two sector-specific models capture these effects in biological modules. They account also for some land management choices and other adaptation possibilities (input use, changes to varieties, sowing and harvesting dates, etc.). We consider demography to be the main driver of urban land use change.

Agriculture and forestry are the two land based sectors that are the most exposed to climate change effects. Nevertheless, these two sectors have numerous options for adaptation to the new climate conditions. In the sector-specific model for agriculture (AROPAj) used in the present study, farmers can change crops or crop varieties, sowing and harvesting dates, and intensity of their inputs (fertilizer) as well as the number of animals per hectare in the case of pasture. Farmers also switch between pasture and crops, and vice versa. Forestry managers modeled by the FFSM++ model have the possibility to adapt through the choice of tree species. The land use share model allows us to account also for possible adaptations through land use change. The estimated coefficients of the land use share model are provided in appendix D

Results concerning climate induced land use change indicate that we can expect crop land to expand at the expense of forests and pastures (Lungarska and Chakir, 2018).

Public policy simulations We study two command-and-control policy options aimed at limiting intensive agricultural land and intensive pasture. As our estimation results show, intensive agriculture and pasture have the largest effects on freshwater biodiversity. We thus exploit this information by simulating the effects of land management policies 
on freshwater biodiversity. We consider a reduction in the intensity of nitrogen fertilizer use on crops and a reduction in livestock density on pastures.

To control local water pollution problems, regulatory instruments such as standards are more frequent in France than fiscal measures. This is because the precise location of pollution is important, and can be considered only imperfectly by fiscal measures (Ministère de l'environnement, 2017).

The policy options are designed in the following way. As explained before, agricultural land and pasture land are each decomposed into four land use classes based on intensification (high/low) and slope (high/low). In the case of agricultural land, the intensification criterion is nitrogen fertilizer use per hectare, and in the case of pasture the criterion is livestock density. The first regulation involves shifting from intensive uses in favor of extensive uses for agricultural land in the same slope class. The second policy involves the same shift for pasture.

As the FBI model estimation results show (see table 12), all intensive cropping and pasture land uses (agr2, agr4, pst2, and pst4) have a positive and significant effect on the FBI score, and thus, a negative impact on fish populations. Our simulations involve shifting from intensive uses (in agriculture and pasture) to extensive uses for a given slope type (high or low).

Table 4 summarizes the reductions in livestock units and nitrogen fertilizer use for the different policy and climate change scenarios. Overall, a standard for intensive pasture leads to a 32\%-35\% decrease in livestock units. The reduction in livestock units for intensive farms (with more than 0.7 livestock units/ha) is $42 \%-44 \%$. The associated reductions in nitrogen fertilizer use in these scenarios (table 4 ) range between $49 \%$ and $58 \%$ overall, and from $57 \%$ to $62 \%$ for intensive farms (with more than $100 \mathrm{kgN} / \mathrm{ha}$ fertilizer applications).

\subsubsection{Simulation results}

Our simulation results are summarized in figure 5 . As the estimations of the FBI index are subject to prediction errors, the assignment in specific water classes resulting from these FBI estimations is also subject to the prediction 


\begin{tabular}{lcccc}
\hline $\begin{array}{l}\text { Policy } \\
\text { scenario }\end{array}$ & \multicolumn{2}{c}{ Pasture policy } & \multicolumn{2}{c}{ Agricultural policy } \\
\hline $\begin{array}{l}\text { Policy } \\
\text { outcomes }\end{array}$ & $\begin{array}{c}\text { Livestock units } \\
\text { reduction }\end{array}$ & $\begin{array}{c}\text { Livestock units reduction } \\
\text { in intensive farms }\end{array}$ & $\begin{array}{c}\text { Overall nitrogen } \\
\text { reduction }\end{array}$ & $\begin{array}{c}\text { Nitrogen reduction } \\
\text { in intensive farms }\end{array}$ \\
\hline $\begin{array}{l}\text { Current } \\
\text { climate }\end{array}$ & $-32.12 \%$ & $-41.79 \%$ & $-49.44 \%$ & $-56.91 \%$ \\
A2 & $-34.8 \%$ & $-43.66 \%$ & $-58.43 \%$ & $-62.5 \%$ \\
B1 & $-34.54 \%$ & $-43.14 \%$ & $-55.28 \%$ & $-59.79 \%$ \\
\hline
\end{tabular}

Table 4: Reductions in livestock units and nitrogen fertilizer use for the climate and policy scenarios

errors. For this reason, we provide in appendix E (figures 7, 8, and 9), the prediction intervals of FBI associated with each scenario and the water quality classes.

The impact of climate change on the FBI is shown clearly by comparing the maps given at the three rows in the first column of figure 5. The predictions for the current climate conditions are depicted at the top of the figure, those for climate change scenario $\mathrm{B} 1$ are in the middle, and those for climate change scenario A2 are at the bottom of the figure. It can be seen that the FBI is worse under the two climate change scenarios compared to the current climate; scenarios A2 and B1 show more hydrographic sectors registering "Mediocre", "Bad" and "Very bad" quality (figures 9 and 8 in appendix E). These results are driven by expansion in agriculture and urban land uses, and the evolution of climate variables (increased temperature and coefficient of variation in precipitation). The maps in figure 5 show also that water quality is worse in the A2 scenario compared to the B1. Recall here that the A2 scenario is considered a pessimistic scenario, and thus, is associated to a greater temperature increase than the B1 scenario. Also, the A2 scenario is supposed to lead to a greater increase in urban area since it assumes a larger French population increase.

The effects of a standard for livestock density can be evaluated by comparing the maps in the first column of figure 5("status quo") with those in the second column of the figure ("pasture policy" scenario). Under the current climate scenario (top of figure 5), the limitations on intensive pasture allow some hydrographic sectors to recover, 
resulting in fewer observations of "Bad" and "Very bad" quality. Comparison of the maps shows that in some sectors such as those located in the Massif Central (mid Southern France) quality is worsened by the standard. In these sectors, pastures are mostly steeply sloped and with high intensity (see figure 4), and the pasture policy suggests that these pastures would shift to steep slope, low intensity. However, the FBI coefficient of the latter is higher than the FBI coefficient of the former which results in higher pressure on fish populations. Finally, this standard is not sufficient to compensate for the adverse impacts of climate change on water quality. In fact, if the policy applies to the two climate change scenarios, there are fewer "Good" and "Very good" water quality hydrographic sectors than under the current climate regime.

The effects of a standard on nitrogen fertilizer use for agriculture represented in the third column of figure 5 show that under the current climate the simulated policy improves water quality, and some $60 \%$ of the hydrographic sectors are classed as "Good" or "Very good", while those classed as in a "Bad" state reduce from 10 to 3 sectors. As in the case of pasture policy, the agricultural policy is not able to fully offset the adverse impacts of climate change on water quality.

Under which scenario does France comply with the EU WFD? Table 5 summarizes the simulation results for the different climate and policy scenarios. It represents the share of good and very good quality hydrographic sectors in terms of FBI score. Recall that to comply with the objective of the EU WFD, France (like the other EU member states) needs to achieve good or very good surface water quality for $60 \%$ of its water resources by 2021. Regarding the effects of climate change and land use adaptation, freshwater biodiversity deteriorates, and that loss of biodiversity would be larger in the case of the pessimistic A2 climate change scenario. These results show that land use adaptation to climate change could imply adverse effects for freshwater biodiversity. Our results add to the findings in the literature on the unintended effects of climate adaptation on chemical water pollution (Fezzi et al., 2015) and bird populations (Beaudry et al., 2013; Ay et al., 2014)

In relation to the impacts of agricultural and pasture policies, both improve freshwa- 


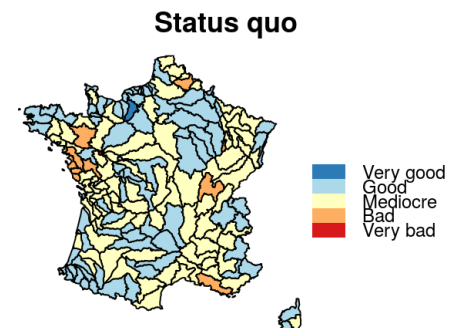

(5)

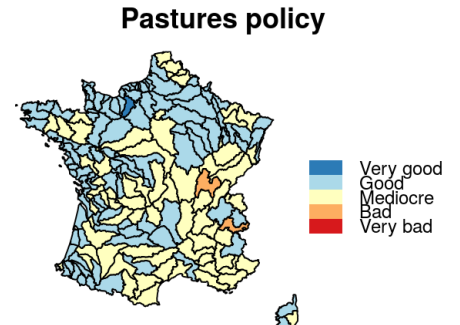

S

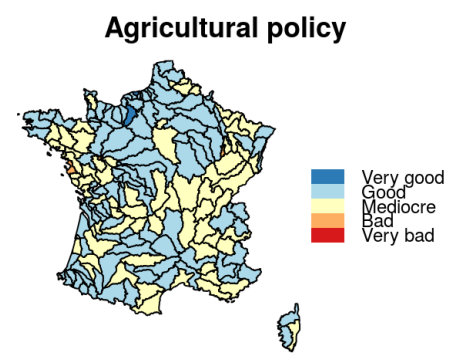

(5)
$46.1 \%$

Share of the sectors in "Good" or "Very Good" classes

$50.0 \%$

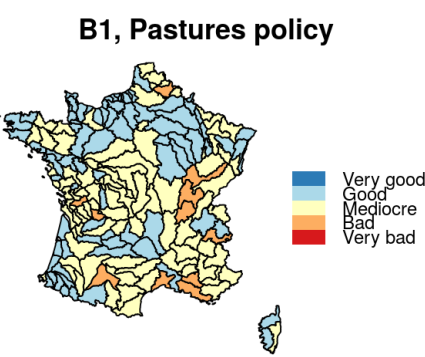

$60.0 \%$

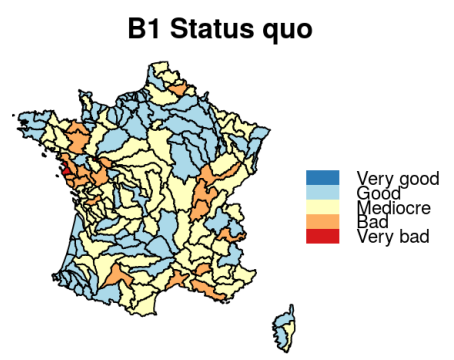

Share of the sectors in "Good" or "Very Good" classes

$42.5 \%$

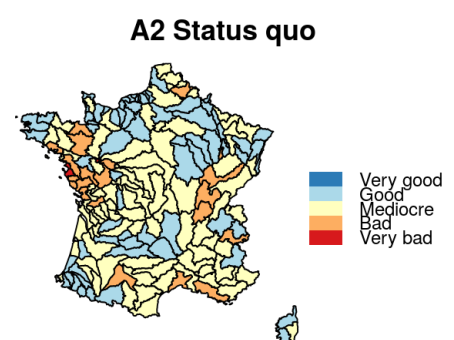

Share of the sectors in "Good"

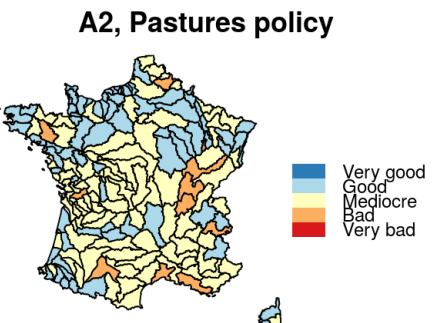

9

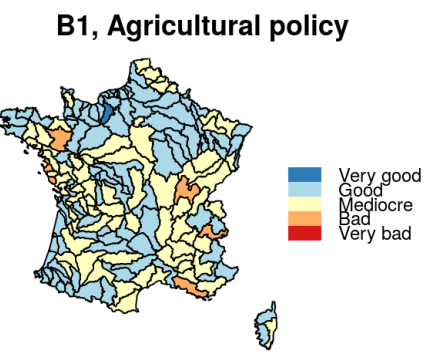

$56.4 \%$ $38.7 \%$ $42.0 \%$

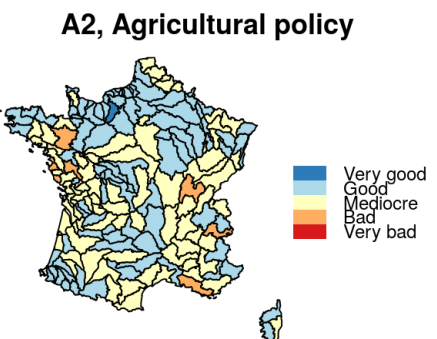

(1) $50.8 \%$

Figure 5: Simulation results for water quality based on FBI index under current climate (top row) and future climate change scenarios (B1 scenario, middle row; A2 scenario, bottom row), and for the two land use policies (Pasture policy, second column; Agricultural policy, third column). The agricultural policy outperforms the pasture policy for all climate scenarios. Water quality is worse under climate change. Moreover, the B1 scenario leads to better results than the A2 scenario regardless of the policy in place.

\begin{tabular}{lccc}
\hline Scenario & Status quo & Pasture policy & Agricultural policy \\
\hline Current climate & $46.1 \%$ & $50.0 \%$ & $60.0 \%$ \\
B1 scenario & $42.5 \%$ & $45.3 \%$ & $56.4 \%$ \\
A2 scenario & $38.7 \%$ & $42.0 \%$ & $50.8 \%$ \\
\hline
\end{tabular}

Table 5: The share of hydrographic sectors with good and very good quality in terms of the FBI score 
ter biodiversity compared to the status quo. When we take into account the combined effects of the policies and the climate change scenarios, we note first that the two policies do not fully compensate for the adverse impacts of climate change on biodiversity. The better positioned sectors are still less than the $60 \%$ hydrographic sectors requirement to conform to the EU WFD. Note also that the agricultural policy allows France to comply with the EU WFD under the current climate but not under future climate change scenarios.

\section{Conclusion}

The status of some rivers in France is highly degraded, exemplified by a decline in the quality and quantity of water and changes in the distribution and structure of aquatic biota (Oberdorff et al., 2002). French freshwater fish populations have suffered from degradation and destruction of natural environments, and pollution. Pressures on freshwater ecosystems are mainly human-induced and driven by land use and climate change. The objective of this paper was to evaluate how land use and land use adaptation to climate change affect freshwater ecosystems in France.

We used data on land use shares (agriculture, pasture, forest, urban and other) and on FBI, an indicator of the ecological status of surface water, measured for various French rivers observed between 2001 and 2013. We estimated two models: a spatial econometric land use share model, and a statistical spatial panel FBI model. The land use share model describes how land use is affected by economic, pedo-climatic and demographic factors, while the FBI model explains the spatial and temporal distribution of the FBI score by land use and pedo-climatic variables.

Regarding the effects of alternative land uses, our estimation results reveal that rivers in areas with more agricultural, pasture and urban land relative to forest, are associated to lower freshwater biodiversity. They also show that the harmful effect of the agricultural sector (crops and pasture) is larger than that of the urban land use on freshwater biodiversity. Regarding the effects of land management options, our estimations provide interesting results. They show that intensive crops and high slope pasture reduce freshwater biodiversity the most relative to forest land use. 
Another result worthwhile to stress is that extensive pasture is not necessarily good for freshwater biodiversity as usually mentioned in the literature. According to Steinfeld et al. (2006) extensive livestock systems may provide environmental services of vegetation cover and biodiversity while intensive livestock production contributes to eutrophication of surface and ground water ecosystems. Our results show that extensive pasture in steep areas reduce freshwater biodiversity relative to forest land use. This is an important result as it is well known that steep slopes increase the speed of the water flow leading to increasing run-off and soil erosion over time. These overall findings highlight the importance of distinguishing crop and pasture land uses with respect to intensive/extensive practices and topological characteristics when evaluating their impacts on freshwater biodiversity.

Based on our estimation results, our simulations show that land use adaptation to climate change reduces freshwater biodiversity. The loss in biodiversity is larger in the case of the more pessimistic climate change scenario. We also discussed how two command-and-control policy options might help to improve freshwater biodiversity and mitigate the adverse impacts of climate change on this biodiversity. These policy options are a standard for nitrogen fertilizer use in agriculture, and a standard for livestock density on pasture. Our simulations show that the agricultural policy would allow France to comply with the EU WFD under the current climate. However, neither of the two policies makes compliance with the EU WFD under the climate change scenarios. This indicates that simulating the mere effects of public policies without including the climate change impacts would lead to the over-estimation of the benefits from these policies. This, in turn, could introduce a bias in terms of the policy action recommendations within the EU WFD.

The relatively poor performance of agricultural and pasture policies considered in this paper needs to be nuanced. Our study considers only land regulations that do not vary over the territory. The policies do not discriminate policy variables with respect to pedo-climatic conditions. It could be interesting to consider the effectiveness of spatially-differentiated regulations for freshwater biodiversity. For instance, policy might recommend a reduction in the intensiveness of pasture in high slope areas, or an agri- 
cultural policy might set some limits on intensive crop production located at upstream points or in environmentally vulnerable areas. Furthermore, we focused on separate regulations for pasture and crop production but there are other possibilities. Mixed policies can be investigated also by considering the interaction effects on freshwater biodiversity between pasture and agricultural policies.

Our analysis of the impacts of land use and climate change on FBI is subject to uncertainties related mainly to climate scenarios. These uncertainties are due to both incomplete and unknowable knowledge. The best way to quantify some of these uncertainties is to use a probabilistic framework. Using a statistical approach, Raftery et al. (2017) estimate an increase in temperature by 2100 between $2^{\circ} \mathrm{C}$ and $4.9^{\circ} \mathrm{C}$, with a median value of $3.2^{\circ} \mathrm{C}$. According to the same study, the probability of limiting global warming to $2^{\circ} \mathrm{C}$ by 2100 as set by the Paris agreement on climate is equal to $5 \%$ and the chances of achieving the $1.5^{\circ} \mathrm{C}$ target, also contained in the same agreement, are only $1 \%$. The two scenarios considered in our paper assume global temperature increase between $2^{\circ} \mathrm{C}$ and $5.4^{\circ} \mathrm{C}$ (A2), and $1.1^{\circ} \mathrm{C}$ and $2.9^{\circ} \mathrm{C}$ (B1). This means that the pessimistic scenario is the most likely one and that our chosen scenarios allow us to have a range of results on climate and land use impacts on FBI taking into account uncertainties on climate scenarios. Our simulations of the impacts of land use policies and climate change on freshwater biodiversity should be extended in the light of new climate scenarios and new knowledge on global systems.

Acknowledgments: The authors are grateful for very helpful comments from the editor and the reviewers. We would like to thank Pierre-Alain Jayet for the data on land shadow prices and Antonello Lobianco for the data on forest rents. We would also like to thank Hervé Dakpo, Nathalie de Noblet and Thierry Oberdorff for useful advices. We thank the participants of the seminar of INRA-LEF (Nancy) for their insightful suggestions. Helpful comments have also been recevived at the following conferences: 18th Annual BIOECON Conference(Cambridge), EcoMod Conference (Lisbon), the 23rd Annual Conference of the EAERE (Athens), the XV EAAE Congress (Parma), the AFSE Conference (Paris). We acknowledge the support of the European Union within the European Commission Seventh Framework Programme in the frame of RURAGRI ERA-NET under Grant Agreement 235175 TRUSTEE (ANR13-RURA-0001-01), and of the Agence Nationale de la Recherche within STIMUL (Scenarios Towards 
integrating multi-scale land use tools) flagship project as part of the "Investments d'Avenir" Programme (LabEx BASC; ANR-11-LABX-0034). Neither the French Agence Nationale de la Recherche nor any European Union or European Commission organization is accountable for the content of this research. The authors are solely responsible for any omissions or deficiencies.

\section{References}

Abildtrup, J., Garcia, S., and Stenger, A. (2013). The effect of forest land use on the cost of drinking water supply: A spatial econometric analysis. Ecological Economics, 92:126 - 136.

Allan, J. D. (2004). Landscapes and Riverscapes: The Influence of Land Use on Stream Ecosystems. Annual Review of Ecology, Evolution, and Systematics, 35(1):257-284.

Atasoy, M., Palmquist, R. B., and Phaneuf, D. J. (2006). Estimating the effects of urban residential development on water quality using microdata. Journal of environmental management, 79(4):399-408.

Ay, J. S., Chakir, R., Doyen, L., Jiguet, F., and Leadley, P. (2014). Integrated models, scenarios and dynamics of climate, land use and common birds. Climatic Change, 126(1-2):13-30.

Ay, J.-S., Chakir, R., and Gallo, J. L. (2017). Aggregated versus individual land-use models: Modeling spatial autocorrelation to increase predictive accuracy. Environmental Modeling $\&$ Assessment, 22(2):129-145.

Bates, B., Kundzewicz, Z., and Wu, S. (2008). Climate change and water. Technical Paper of the Intergovernmental Panel on Climate Change, IPCC Secretariat, Geneva, 210 pp.

Beaudry, F., Radeloff, V. C., Pidgeon, A. M., Plantinga, A. J., Lewis, D. J., Helmers, D., and Butsic, V. (2013). The loss of forest birds habitats under different land use policies as projected by a coupled ecological-econometric model. Biological conservation, 165:1-9.

Caurla, S., Delacote, P., Lecocq, F., Barthès, J., and Barkaoui, A. (2013). Combining an inter-sectoral carbon tax with sectoral mitigation policies: Impacts on the french forest sector. Journal of Forest Economics, 19(4):450-461.

Center for International Earth Science Information Network (2002). Country-level Population and Downscaled Projections based on the A1, B1, A2 and B2 Scenarios, 1990-2100, [digital version]. http://www.ciesin.columbia.edu/datasets/downscaled

Chakir, R. and Le Gallo, J. (2013). Predicting land use allocation in france: A spatial panel data analysis. Ecological Economics, 92(0):114-125.

Chakir, R. and Lungarska, A. (2017). Agricultural rent in land-use models: comparison of frequently used proxies. Spatial Economic Analysis, 12(2-3):279-303. 
De Chazal, J. and Rounsevell, M. D. (2009). Land-use and climate change within assessments of biodiversity change: a review. Global Environmental Change, 19(2):306-315.

Eaufrance (2015). L'état des eaux de surface et des eaux souterraines. Technical report, Eaufrance, Les Synthèses, $\mathrm{n}^{\circ} 12$ - Juin 2015.

Fezzi, C., Harwood, A. R., Lovett, A. A., and Bateman, I. J. (2015). The environmental impact of climate change adaptation on land use and water quality. Nature Climate Change, 5(4):385-385.

Fiquepron, J., Garcia, S., and Stenger, A. (2013). Land use impact on water quality: Valuing forest services in terms of the water supply sector. Journal of environmental management, 126:113-121.

Hascic, I. and Wu, J. (2006). Land use and watershed health in the united states. Land Economics, $82(2): 214-239$

IPBES (2018). Summary for policymakers of the regional assessment report on biodiversity and ecosystem services for europe and central asia of the intergovernmental science-policy platform on biodiversity and ecosystem services. Technical report, M. Fischer, M. Rounsevell, A. Torre-Marin Rando, A. Mader, A. Church, M. Elbakidze, V. Elias, T. Hahn. P.A. Harrison, J. Hauck, B. Martín-López, I. Ring, C. Sandström, I. Sousa Pinto, P. Visconti, N.E. Zimmermann and M. Christie (eds.).

IPCC (2000). Special report on emissions scenarios. Special Report on Emissions Scenarios, Edited by Nebojsa Nakicenovic and Robert Swart, pp. 612. ISBN 0521804930. Cambridge, UK: Cambridge University Press, July 2000., 1.

Jayet, P.-A., Petsakos, A., Chakir, R., Lungarska, A., De Cara, S., Petel, E., Humblot, P., Godard, C., Leclère, D., Cantelaube, P., Bourgeois, C., Bamière, L., Ben Fradj, N., Aghajanzadeh-Darzi, P., Dumollard, G., Ancuta, I., and Adrian, J. (2015). The European agro-economic AROPAj model. INRA, UMR Economie Publique, Thiverval-Grignon. https://www6.versailles-grignon.inra.fr/ economie_publique_eng/Research-work.

Keeler, B. L. and Polasky, S. (2014). Land-use change and costs to rural households: a case study in groundwater nitrate contamination. Environmental Research Letters, 9(7):074002.

Kernan, M., Battarbee, R. W., and Moss, B. R. (2011). Climate change impacts on freshwater ecosystems. John Wiley \& Sons.

Langpap, C., Hascic, I., and Wu, J. (2008). Protecting watershed ecosystems through targeted local land use policies. American Journal of Agricultural Economics, 90(3):684-700.

Leclère, D., Jayet, P.-A., and de Noblet-Ducoudré, N. (2013). Farm-level autonomous adaptation of european agricultural supply to climate change. Ecological Economics, 87(0):1 - 14.

LeSage, J. and Pace, R. (2009). Introduction to spatial econometrics. CRC Press, Boca Raton FL. 
Lewis, Plantinga, Nelson, and Polasky (2011). The efficiency of voluntary incentive policies for preventing biodiversity loss. Ressource and Energy Economics, (07):1-38.

Lichtenberg, E. (1989). Land quality, irrigation development, and cropping patterns in the northern high plains. American Journal of Agricultural Economics, Vol. 71, No. 1:187-194.

Lobianco, A., Delacote, P., Caurla, S., and Barkaoui, A. (2016). Accounting for active management and risk attitude in forest sector models. Environmental Modeling \& Assessment, 21:391-405.

Lungarska, A. and Chakir, R. (2018). Climate-induced land use change in france: Impacts of agricultural adaptation and climate change mitigation. Ecological Economics, 147:134 - 154.

Lungarska, A. and Jayet, P.-A. (2018). Impact of Spatial Differentiation of Nitrogen Taxes on French Farms' Compliance Costs. Environmental and Resource Economics, 69(1):1-21.

Martin, Y., Van Dyck, H., Dendoncker, N., and Titeux, N. (2013). Testing instead of assuming the importance of land use change scenarios to model species distributions under climate change. Global Ecology and Biogeography, 22(11):1204-1216.

Martinho, F., Nyitrai, D., Crespo, D., and Pardal, M. A. (2015). Efficacy of single and multi-metric fish-based indices in tracking anthropogenic pressures in estuaries: An 8-year case study. Marine Pollution Bulletin, 101(1):153-162.

Martinuzzi, S., Gavier-Pizarro, G. I., Lugo, A. E., and Radeloff, V. C. (2015). Future Land-Use Changes and the Potential for Novelty in Ecosystems of the United States. Ecosystems, 18(8):1332-1342.

Millennium Ecosystem Assessment (2005). Ecosystems and human well-being: Wetlands and water synthesis. Washington, DC.

Miller, D. J. and Plantinga, A. J. (1999). Modeling land use decisions with aggregate data. American Journal of Agricultural Economics, 81(1):180-194.

Ministère de l'environnement (2017). Fiscalité environnementale en France. Un état des lieux. Technical report, Ministère de l'environnement, de l'énergie et de la mer, CGDD Service de l'économie, de l'évaluation et de l'intégration du développement durable.

Oberdorff, T., Pont, D., Hugueny, B., and Porcher, J.-P. (2002). Development and validation of a fish-based index for the assessment of river health in france. Freshwater Biology, 47(9):1720-1734.

Onema/OIEau (2015). L'état des eaux de surface et des eaux souterraines. Technical report, Données : Etats des lieux - Agences de l'eau, DREAL délégations de bassin 2013.

Pagé, C. and Terray, L. (2010). Nouvelles projections climatiques à échelle fine sur la France pour le 21ème siècle : les scénarii SCRATCH2010. Technical Report TR/CMGC/10/58, SUC au CERFACS, URA CERFACS/CNRS No1875CS, Toulouse, France. 
Pagé, C., Terray, L., and Boé, J. (2010). Cdsclim: A software package to downscale climate scenarios at regional scale using a weather-typing based statistical methodology. Technical Report TR/CMGC/09/21, SUC au CERFACS, URA CERFACS/CNRS No1875, Toulouse, France.

Panagos, P., Van Liedekerke, M., Jones, A., and Montanarella, L. (2012). European soil data centre: Response to european policy support and public data requirements. Land Use Policy, 29(2):329-338.

Pereira, H. M., Leadley, P. W., Proença, V., Alkemade, R., Scharlemann, J. P., Fernandez-Manjarrés, J. F., Araújo, M. B., Balvanera, P., Biggs, R., Cheung, W. W., et al. (2010). Scenarios for global biodiversity in the 21st century. Science, 330(6010):1496-1501.

Peyraud, J., Cellier, P., Donnars, C., Vertes, F., Aarts, F., Béline, F., Bockstaller, C., Bourblanc, M., Delaby, L., Dourmad, J.-Y., Dupraz, P., Durand, P., Faverdin, P., Fiorelli, J.-L., Gaigné, C., Girard, A., Guillaume, F., Kuikman, P., Langlais, A., Le Goffe, P., Le Perchec, S., Lescoat, P., Morvan, T., Nicourt, C., Parnaudeau, V., Rechauchère, O., Rochette, P., and Veysset, P. (2014). Réduire les pertes d'azote dans l'élevage. Matière à débattre et décider. Editions Quae, Versailles FRA.

Plantinga, A. J. (1996). The effect of agricultural policies on land use and environmental quality. American Journal of Agricultural Economics, 78(4):1082-1091.

Raftery, A. E., Zimmer, A., Frierson, D. M., Startz, R., and Liu, P. (2017). Less than $2^{\circ} \mathrm{C}$ warming by 2100 unlikely. Nature Climate Change, 7(9):637.

Runting, R. K., Bryan, B. A., Dee, L. E., Maseyk, F. J., Mandle, L., Hamel, P., Wilson, K. A., Yetka, K., Possingham, H. P., and Rhodes, J. R. (2017). Incorporating climate change into ecosystem service assessments and decisions: a review. Global change biology, 23(1):28-41.

Shortle, J. S. and Horan, R. D. (2002). The Economics of Nonpoint Pollution Control. Journal of Economic Surveys, 15(3):255-289.

SOeS (2012). L'état des peuplements piscicoles par station de suivi des rivières http://www.statistiques.developpement-durable.gouv.fr/indicateurs-indices/f/1831/1346/letatpeuplements-piscicoles.html. Technical report, Commissariat général au développement durable Service de l'observation et des statistiques.

Stavins, R. N. and Jaffe, A. B. (1990). Unintended impacts of public investments on private decisions: The depletion of forested wetlands. American Economic Review, 80(3):337-352.

Steinfeld, H., Gerber, P., Wassenaar, T., Castel, V., Rosales, M., and Haan, C. (2006). Livestock's long shadow: environmental issues and options. Technical report, FAO.

UICN France, MNHN, SFI, ONEMA (2010). La liste rouge des espèces menacées en france - chapitre poissons d'eau douce de france métropolitaine. Technical report. 
Whitfield, A. K. and Elliott, M. (2002). Fishes as indicators of environmental and ecological changes within estuaries: a review of progress and some suggestions for the future. Journal of Fish Biology, 61(sa):229-250.

Wu, J., Adams, R. M., Kling, C. L., and Tanaka, K. (2004). From microlevel decisions to landscape changes: an assessment of agricultural conservation policies. American Journal of Agricultural Economics, 86(1):26-41.

Wu, J. and Segerson, K. (1995). The impact of policies and land characteristics on potential groundwater pollution in Wisconsin. American Journal of Agricultural Economics, 77(4):1033-1047.

WWF (2016). Living planet report 2016. risk and resilience in a new era. wwf international, gland, switzerland. Technical report.

Xu, J.-F., Yin, W., Ai, L., Xin, X.-K., and Shi, Z.-H. (2016). Spatiotemporal patterns of non-point source nitrogen loss in an agricultural catchment. Water Science and Engineering, 9(2):125-133. 


\section{${ }_{822}$ Appendices}

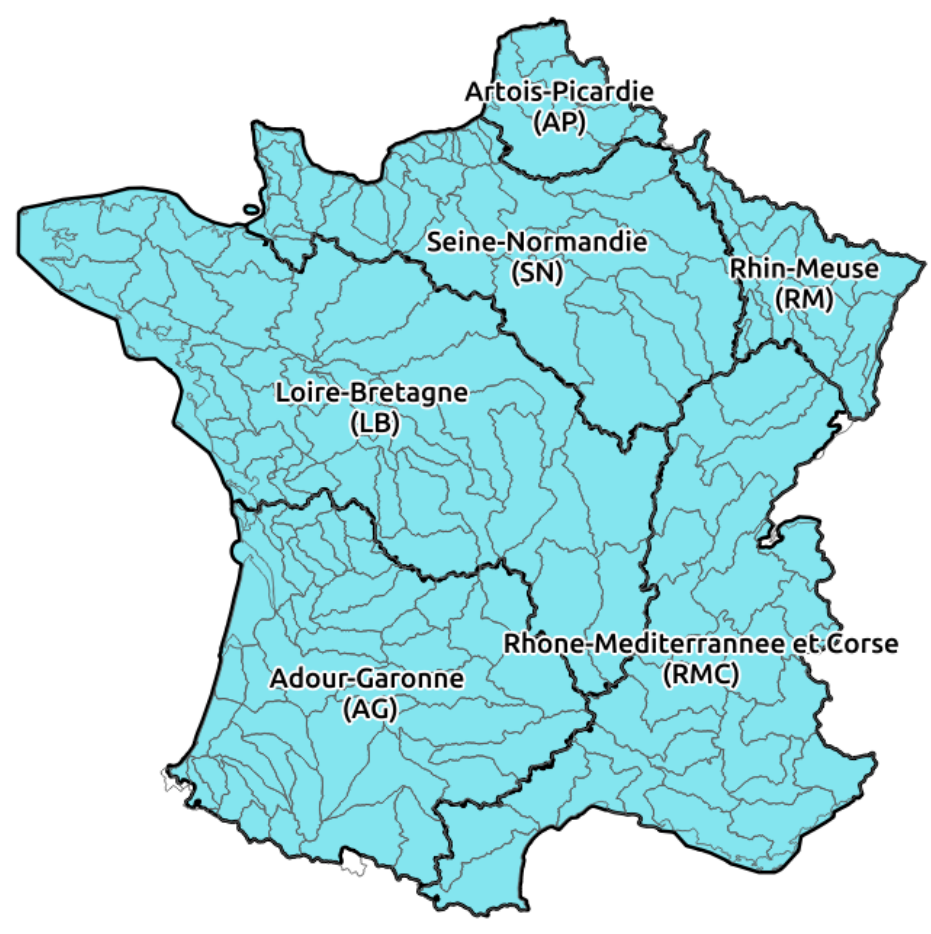

Figure 6: Hydrographic sectors and River bassin districts (RBD, water agencies) in France 


\begin{tabular}{lllll}
\hline Year & Contiguity & Upstream & Contiguity-Upstream & Triangulation \\
\hline 2001 & -0.023 & 0.041 & 0.001 & $0.017 *$ \\
2002 & $0.016^{*}$ & 0.003 & $0.029^{*}$ & $0.043 * *$ \\
2003 & $0.136^{* * *}$ & 0.066 & $0.152^{* * *}$ & $0.137 * * *$ \\
2004 & $0.055^{* *}$ & 0.003 & $0.074^{* *}$ & $0.056^{* * *}$ \\
2005 & $0.122^{* * *}$ & -0.004 & $0.128^{* * *}$ & $0.182^{* * *}$ \\
2006 & $0.116^{* * *}$ & 0.04 & $0.124^{* * *}$ & $0.144 * * *$ \\
2007 & $0.044^{* *}$ & -0.004 & $0.034^{*}$ & $0.055^{* * *}$ \\
2008 & $0.156^{* * *}$ & 0.02 & $0.153^{* * *}$ & $0.115^{* * *}$ \\
2009 & $0.043^{* *}$ & 0.027 & $0.054^{* *}$ & $0.054 * * *$ \\
2010 & $0.143^{* * *}$ & 0.042 & $0.145^{* * *}$ & $0.127 * * *$ \\
2011 & $0.12^{* * *}$ & 0.038 & $0.116^{* * *}$ & $0.088^{* * *}$ \\
2012 & $0.194 * * *$ & 0.125 & $0.21^{* * *}$ & $0.138^{* * *}$ \\
2013 & $0.095^{* * *}$ & 0.077 & $0.095^{* * *}$ & $0.091 * * *$ \\
\hline
\end{tabular}

Table 6: Moran's I for annual OLS models, no fixed effects

\begin{tabular}{lllll}
\hline Year & Contiguity & Upstream & Contiguity-Upstream & Triangulation \\
\hline 2001 & -0.106 & 0 & -0.09 & -0.035 \\
2002 & -0.042 & -0.05 & -0.041 & $0.01 * *$ \\
2003 & $0.016^{* *}$ & -0.001 & $0.022^{* *}$ & $0.043^{* * *}$ \\
2004 & $0.017^{* *}$ & -0.043 & $0.022^{* *}$ & $-0.006 * *$ \\
2005 & $0.073 * * *$ & -0.022 & $0.081^{* * *}$ & $0.119^{* * *}$ \\
2006 & $0.021^{* *}$ & -0.024 & $0.018^{* *}$ & $0.051^{* * *}$ \\
2007 & -0.017 & -0.053 & -0.032 & -0.041 \\
2008 & $0.099^{* * *}$ & 0.005 & $0.116^{* * *}$ & $0.033^{* * *}$ \\
2009 & $-0.013^{*}$ & -0.014 & $-0.001^{*}$ & $0.002^{* *}$ \\
2010 & $0.038^{* *}$ & -0.001 & $0.045^{* *}$ & $0.052^{* * *}$ \\
2011 & $0.033^{* *}$ & -0.028 & $0.024^{* *}$ & -0.039 \\
2012 & $0.044^{* * *}$ & $0.141 *$ & $0.089^{* * *}$ & $0.011^{* *}$ \\
2013 & $-0.014 *$ & 0.059 & $0.001 *$ & $0.022 * *$ \\
\hline
\end{tabular}

Table 7: Moran's I for annual OLS models, RBD fixed effects 
B Models without fixed effects

\begin{tabular}{|c|c|c|c|c|}
\hline Variable & OLS & $\mathrm{RE}$ & SEM & SEM-RE \\
\hline (Intercept) & $\begin{array}{l}1.5857 \text { *** } \\
(0.1515)\end{array}$ & $\begin{array}{l}2.0439 \text { *** } \\
(0.2635)\end{array}$ & $\begin{array}{l}1.6589 \text { *** } \\
(0.1625)\end{array}$ & $\begin{array}{l}2.073 \text { *** } \\
(0.273)\end{array}$ \\
\hline Texture (cl. 2) & $\begin{array}{l}0.2778^{* * *} \\
(0.076)\end{array}$ & $\begin{array}{l}0.4226 \text { ** } \\
(0.1958)\end{array}$ & $\begin{array}{l}0.2631 \text { *** } \\
(0.0736)\end{array}$ & $\begin{array}{l}0.4202 \text { ** } \\
(0.191)\end{array}$ \\
\hline Texture (cl. 3) & $\begin{array}{l}-0.1082 \\
(0.0739)\end{array}$ & $\begin{array}{c}-0.0155 \\
(0.1932)\end{array}$ & $\begin{array}{l}-0.0886 \\
(0.0769)\end{array}$ & $\begin{array}{l}-0.0126 \\
(0.1975)\end{array}$ \\
\hline Texture (cl. 4) & $\begin{array}{l}0.3317^{* * *} \\
(0.1036)\end{array}$ & $\begin{array}{l}0.4389 \\
(0.2742)\end{array}$ & $\begin{array}{l}0.3719^{* * *} \\
(0.107)\end{array}$ & $\begin{array}{l}0.467 * \\
(0.2784)\end{array}$ \\
\hline rain_cv & $\begin{array}{l}-0.0101 \\
(0.0442)\end{array}$ & $\begin{array}{l}-1 \mathrm{e}-04 \\
(0.0321)\end{array}$ & $\begin{array}{l}-0.0031 \\
(0.0541)\end{array}$ & $\begin{array}{l}4 \mathrm{e}-04 \\
(0.0371)\end{array}$ \\
\hline $\mathrm{T}$ & $\begin{array}{l}0.0225^{* *} \\
(0.0095)\end{array}$ & $\begin{array}{l}0.0161 \\
(0.0122)\end{array}$ & $\begin{array}{l}0.0163 \\
(0.0111)\end{array}$ & $\begin{array}{l}0.012 \\
(0.0145)\end{array}$ \\
\hline agr1 & $\begin{array}{l}1.3077^{* * *} \\
(0.1896)\end{array}$ & $\begin{array}{l}0.8979 * * \\
(0.4493)\end{array}$ & $\begin{array}{l}1.2766 \text { *** } \\
(0.1865)\end{array}$ & $\begin{array}{l}0.9965 \text { ** } \\
(0.4467)\end{array}$ \\
\hline agr2 & $\begin{array}{l}1.6411 \text { *** } \\
(0.1715)\end{array}$ & $\begin{array}{l}1.2068 \text { *** } \\
(0.3968)\end{array}$ & $\begin{array}{l}1.635 * * * \\
(0.1739)\end{array}$ & $\begin{array}{l}1.3257^{* * *} \\
(0.4053)\end{array}$ \\
\hline agr3 & $\begin{array}{l}0.5659 \text { *** } \\
(0.1614)\end{array}$ & $\begin{array}{l}-0.0682 \\
(0.3667)\end{array}$ & $\begin{array}{l}0.6838 \text { *** } \\
(0.165)\end{array}$ & $\begin{array}{l}0.0316 \\
(0.3762)\end{array}$ \\
\hline agr4 & $\begin{array}{l}0.3807 \text { *** } \\
(0.1239)\end{array}$ & $\begin{array}{l}-0.1201 \\
(0.2875)\end{array}$ & $\begin{array}{l}0.4038^{* * *} \\
(0.1239)\end{array}$ & $\begin{array}{l}-0.0808 \\
(0.2914)\end{array}$ \\
\hline pst1 & $\begin{array}{l}-3.7076^{* * *} \\
(0.9102)\end{array}$ & $\begin{array}{l}-5.1257^{* *} \\
(2.2187)\end{array}$ & $\begin{array}{l}-3.3578 \text { *** } \\
(0.9402)\end{array}$ & $\begin{array}{l}-5.631 * * \\
(2.2433)\end{array}$ \\
\hline pst2 & $\begin{array}{l}2.00511^{* * *} \\
(0.386)\end{array}$ & $\begin{array}{l}1.1779 \\
(0.9645)\end{array}$ & $\begin{array}{l}1.9849 \text { *** } \\
(0.4161)\end{array}$ & $\begin{array}{l}0.9209 \\
(1.0056)\end{array}$ \\
\hline pst3 & $\begin{array}{l}3.605 * * * \\
(0.3054)\end{array}$ & $\begin{array}{l}2.7779 \text { *** } \\
(0.7189)\end{array}$ & $\begin{array}{l}3.0786 \text { *** } \\
(0.3093)\end{array}$ & $\begin{array}{l}2.5368 \text { *** } \\
(0.7359)\end{array}$ \\
\hline pst4 & $\begin{array}{l}1.0467 \text { *** } \\
(0.2118)\end{array}$ & $\begin{array}{l}0.5431 \\
(0.4974)\end{array}$ & $\begin{array}{l}0.9312 \text { *** } \\
(0.2239)\end{array}$ & $\begin{array}{l}0.4902 \\
(0.5172)\end{array}$ \\
\hline urb00 & $\begin{array}{l}1.6907^{* * *} \\
(0.2429)\end{array}$ & $\begin{array}{l}1.0064 * \\
(0.5865)\end{array}$ & $\begin{array}{l}1.7578 \text { *** } \\
(0.2535)\end{array}$ & $\begin{array}{l}1.01 * \\
(0.6084)\end{array}$ \\
\hline oth00 & $\begin{array}{l}1.7594 \text { *** } \\
(0.2667)\end{array}$ & $\begin{array}{l}0.2513 \\
(0.4727)\end{array}$ & $\begin{array}{l}1.5262 \text { *** } \\
(0.2654)\end{array}$ & $\begin{array}{l}0.1616 \\
(0.473)\end{array}$ \\
\hline y2003 & $\begin{array}{l}0.0677^{*} \\
(0.0358)\end{array}$ & $\begin{array}{l}0.0709 \text { *** } \\
(0.0266)\end{array}$ & $\begin{array}{l}0.0722 \\
(0.049)\end{array}$ & $\begin{array}{l}0.0744 \text { ** } \\
(0.0325)\end{array}$ \\
\hline phi & & $1.0162 * * *$ & & $0.9788 * * *$ \\
\hline rho & & & $0.3012 * * *$ & $0.199 * * *$ \\
\hline $\mathrm{N}$ & 1586 & 1586 & 1586 & 1586 \\
\hline McFadden pseudo R2 & 0.195 & 0.646 & 0.236 & 0.667 \\
\hline McFadden pseudo R2 (adj.) & 0.175 & 0.626 & 0.216 & 0.647 \\
\hline Log. Lik. & -669.86 & -294.4 & -635.84 & -276.76 \\
\hline
\end{tabular}

Table 8: Models based on the contiguity neighborhood matrix 


\begin{tabular}{|c|c|c|c|c|}
\hline Variable & OLS & $\mathrm{RE}$ & SEM & SEM-RE \\
\hline (Intercept) & $\begin{array}{l}1.5857 \text { *** } \\
(0.1515)\end{array}$ & $\begin{array}{l}2.0439 * * * \\
(0.2635)\end{array}$ & $\begin{array}{l}1.702 \text { *** } \\
(0.1612)\end{array}$ & $\begin{array}{l}2.1022 \text { *** } \\
(0.2724)\end{array}$ \\
\hline Texture (cl. 2) & $\begin{array}{l}0.2778^{* * *} \\
(0.076)\end{array}$ & $\begin{array}{l}0.4226 \text { ** } \\
(0.1958)\end{array}$ & $\begin{array}{l}0.2392 \text { *** } \\
(0.073)\end{array}$ & $\begin{array}{l}0.4065 * * \\
(0.1903)\end{array}$ \\
\hline Texture (cl. 3) & $\begin{array}{l}-0.1082 \\
(0.0739)\end{array}$ & $\begin{array}{l}-0.0155 \\
(0.1932)\end{array}$ & $\begin{array}{l}-0.1174 \\
(0.0775)\end{array}$ & $\begin{array}{l}-0.0281 \\
(0.1981)\end{array}$ \\
\hline Texture (cl. 4) & $\begin{array}{l}0.3317 \text { *** } \\
(0.1036)\end{array}$ & $\begin{array}{l}0.4389 \\
(0.2742)\end{array}$ & $\begin{array}{l}0.3402 \text { *** } \\
(0.1065)\end{array}$ & $\begin{array}{l}0.4548 \\
(0.2774)\end{array}$ \\
\hline rain_cv & $\begin{array}{l}-0.0101 \\
(0.0442)\end{array}$ & $\begin{array}{l}-1 \mathrm{e}-04 \\
(0.0321)\end{array}$ & $\begin{array}{l}-0.0044 \\
(0.0545)\end{array}$ & $\begin{array}{l}-0.0018 \\
(0.0372)\end{array}$ \\
\hline $\mathrm{T}$ & $\begin{array}{l}0.0225 * * \\
(0.0095)\end{array}$ & $\begin{array}{l}0.0161 \\
(0.0122)\end{array}$ & $\begin{array}{l}0.0158 \\
(0.0111)\end{array}$ & $\begin{array}{l}0.0118 \\
(0.0146)\end{array}$ \\
\hline agr1 & $\begin{array}{l}1.3077 \text { *** } \\
(0.1896)\end{array}$ & $\begin{array}{l}0.8979 \text { ** } \\
(0.4493)\end{array}$ & $\begin{array}{l}1.2281 \text { *** } \\
(0.1845)\end{array}$ & $\begin{array}{l}0.9632 * * \\
(0.4442)\end{array}$ \\
\hline agr2 & $\begin{array}{l}1.6411 \text { *** } \\
(0.1715)\end{array}$ & $\begin{array}{l}1.2068 * * * \\
(0.3968)\end{array}$ & $\begin{array}{l}1.6156^{* * *} \\
(0.174)\end{array}$ & $\begin{array}{l}1.3118 \text { *** } \\
(0.4057)\end{array}$ \\
\hline agr3 & $\begin{array}{l}0.5659 \text { *** } \\
(0.1614)\end{array}$ & $\begin{array}{c}-0.0682 \\
(0.3667)\end{array}$ & $\begin{array}{l}0.669 * * * \\
(0.1654)\end{array}$ & $\begin{array}{l}0.0098 \\
(0.3765)\end{array}$ \\
\hline agr4 & $\begin{array}{l}0.3807 * * * \\
(0.1239)\end{array}$ & $\begin{array}{l}-0.1201 \\
(0.2875)\end{array}$ & $\begin{array}{l}0.4121 * * * \\
(0.1242)\end{array}$ & $\begin{array}{l}-0.0812 \\
(0.2921)\end{array}$ \\
\hline pst1 & $\begin{array}{l}-3.7076^{* * *} \\
(0.9102)\end{array}$ & $\begin{array}{l}-5.1257^{* *} \\
(2.2187)\end{array}$ & $\begin{array}{l}-3.41944^{\text {*** }} \\
(0.9364)\end{array}$ & $\begin{array}{l}-5.6928 * * \\
(2.2368)\end{array}$ \\
\hline pst2 & $\begin{array}{l}2.00511^{* * *} \\
(0.386)\end{array}$ & $\begin{array}{l}1.1779 \\
(0.9645)\end{array}$ & $\begin{array}{l}2.006 \text { *** } \\
(0.4145)\end{array}$ & $\begin{array}{l}0.9197 \\
(1.0028)\end{array}$ \\
\hline pst3 & $\begin{array}{l}3.605 * * * \\
(0.3054)\end{array}$ & $\begin{array}{l}2.7779 * * * \\
(0.7189)\end{array}$ & $\begin{array}{l}2.9243 \text { *** } \\
(0.3075)\end{array}$ & $\begin{array}{l}2.4342^{* * *} \\
(0.7343)\end{array}$ \\
\hline pst4 & $\begin{array}{l}1.0467 \text { *** } \\
(0.2118)\end{array}$ & $\begin{array}{l}0.5431 \\
(0.4974)\end{array}$ & $\begin{array}{l}0.9426 \text { *** } \\
(0.2234)\end{array}$ & $\begin{array}{l}0.4961 \\
(0.5173)\end{array}$ \\
\hline urb00 & $\begin{array}{l}1.6907^{* * *} \\
(0.2429)\end{array}$ & $\begin{array}{l}1.0064 * \\
(0.5865)\end{array}$ & $\begin{array}{l}1.7151^{* * *} \\
(0.2502)\end{array}$ & $\begin{array}{l}0.9651 \\
(0.6036)\end{array}$ \\
\hline oth00 & $\begin{array}{l}1.7594 \text { *** } \\
(0.2667)\end{array}$ & $\begin{array}{l}0.2513 \\
(0.4727)\end{array}$ & $\begin{array}{l}1.4767 * * * \\
(0.2617)\end{array}$ & $\begin{array}{l}0.1287 \\
(0.4709)\end{array}$ \\
\hline y2003 & $\begin{array}{c}0.0677 * \\
(0.0358)\end{array}$ & $\begin{array}{l}0.0709 * * * \\
(0.0266)\end{array}$ & $\begin{array}{l}0.073 \\
(0.0497)\end{array}$ & $\begin{array}{l}0.0749 \text { ** } \\
(0.0328)\end{array}$ \\
\hline $\begin{array}{l}\text { phi } \\
\text { rho }\end{array}$ & & $1.0162 * * *$ & & $\begin{array}{l}0.9761 * * * \\
0.2073 * * *\end{array}$ \\
\hline $\begin{array}{l}\text { rho } \\
\text { N }\end{array}$ & 1586 & 1586 & 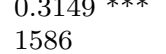 & $\begin{array}{l}0.2073 * * * \\
1586\end{array}$ \\
\hline McFadden pseudo R2 & 0.195 & 0.646 & 0.241 & 0.671 \\
\hline McFadden pseudo R2 (adj.) & 0.175 & 0.626 & 0.221 & 0.65 \\
\hline Log. Lik. & -669.86 & -294.4 & -631.5 & -274.18 \\
\hline
\end{tabular}

Table 9: Models based on the contiguity-upstream neighborhood matrix 


\begin{tabular}{|c|c|c|c|c|}
\hline Variable & OLS & $\mathrm{RE}$ & SEM & SEM-RE \\
\hline (Intercept) & $\begin{array}{l}1.5857 * * * \\
(0.1515)\end{array}$ & $\begin{array}{l}2.0439 * * * \\
(0.2635)\end{array}$ & $\begin{array}{l}1.6205^{* * *} \\
(0.1676)\end{array}$ & $\begin{array}{l}2.0737 \text { *** } \\
(0.2738)\end{array}$ \\
\hline Texture (cl. 2) & $\begin{array}{l}0.2778 \text { *** } \\
(0.076)\end{array}$ & $\begin{array}{l}0.4226 \text { ** } \\
(0.1958)\end{array}$ & $\begin{array}{l}0.2034 \text { *** } \\
(0.0741)\end{array}$ & $\begin{array}{l}0.3746 \text { ** } \\
(0.1907)\end{array}$ \\
\hline Texture (cl. 3) & $\begin{array}{c}-0.1082 \\
(0.0739)\end{array}$ & $\begin{array}{l}-0.0155 \\
(0.1932)\end{array}$ & $\begin{array}{l}-0.0718 \\
(0.0786)\end{array}$ & $\begin{array}{l}-0.0205 \\
(0.1978)\end{array}$ \\
\hline Texture (cl. 4) & $\begin{array}{l}0.3317 \text { *** } \\
(0.1036)\end{array}$ & $\begin{array}{l}0.4389 \\
(0.2742)\end{array}$ & $\begin{array}{l}0.2825 * * * \\
(0.1064)\end{array}$ & $\begin{array}{l}0.4097 \\
(0.2748)\end{array}$ \\
\hline rain_cv & $\begin{array}{l}-0.0101 \\
(0.0442)\end{array}$ & $\begin{array}{l}-1 \mathrm{e}-04 \\
(0.0321)\end{array}$ & $\begin{array}{l}-0.0121 \\
(0.056)\end{array}$ & $\begin{array}{l}0.0031 \\
(0.0375)\end{array}$ \\
\hline $\mathrm{T}$ & $\begin{array}{l}0.0225 \text { ** } \\
(0.0095)\end{array}$ & $\begin{array}{l}0.0161 \\
(0.0122)\end{array}$ & $\begin{array}{l}0.0235 \text { ** } \\
(0.0116)\end{array}$ & $\begin{array}{l}0.012 \\
(0.0149)\end{array}$ \\
\hline agr1 & $\begin{array}{l}1.3077 \text { *** } \\
(0.1896)\end{array}$ & $\begin{array}{l}0.8979^{* *} \\
(0.4493)\end{array}$ & $\begin{array}{l}1.1462 \text { *** } \\
(0.1879)\end{array}$ & $\begin{array}{l}0.9389 * * \\
(0.4473)\end{array}$ \\
\hline agr2 & $\begin{array}{l}1.6411 \text { *** } \\
(0.1715)\end{array}$ & $\begin{array}{l}1.2068 \text { *** } \\
(0.3968)\end{array}$ & $\begin{array}{l}1.3736 \text { *** } \\
(0.1693)\end{array}$ & $\begin{array}{l}1.212 * * * \\
(0.3984)\end{array}$ \\
\hline agr3 & $\begin{array}{l}0.5659 * * * \\
(0.1614)\end{array}$ & $\begin{array}{l}-0.0682 \\
(0.3667)\end{array}$ & $\begin{array}{l}0.6726 \text { *** } \\
(0.1646)\end{array}$ & $\begin{array}{l}0.0754 \\
(0.3757)\end{array}$ \\
\hline agr4 & $\begin{array}{l}0.3807 * * * \\
(0.1239)\end{array}$ & $\begin{array}{l}-0.1201 \\
(0.2875)\end{array}$ & $\begin{array}{l}0.4973 \text { *** } \\
(0.124)\end{array}$ & $\begin{array}{l}0.0087 \\
(0.2912)\end{array}$ \\
\hline pst1 & $\begin{array}{l}-3.7076 \text { *** } \\
(0.9102)\end{array}$ & $\begin{array}{l}-5.1257^{* *} \\
(2.2187)\end{array}$ & $\begin{array}{l}-1.8795 \text { ** } \\
(0.9058)\end{array}$ & $\begin{array}{l}-4.6704 * * \\
(2.1962)\end{array}$ \\
\hline pst2 & $\begin{array}{l}2.0051 \text { *** } \\
(0.386)\end{array}$ & $\begin{array}{l}1.1779 \\
(0.9645)\end{array}$ & $\begin{array}{l}2.4822 \text { *** } \\
(0.4023)\end{array}$ & $\begin{array}{l}1.2225 \\
(0.9785)\end{array}$ \\
\hline pst3 & $\begin{array}{l}3.605 \text { *** } \\
(0.3054)\end{array}$ & $\begin{array}{l}2.7779 * * * \\
(0.7189)\end{array}$ & $\begin{array}{l}2.6033 \text { *** } \\
(0.3136)\end{array}$ & $\begin{array}{l}2.2929 \text { *** } \\
(0.7336)\end{array}$ \\
\hline pst4 & $\begin{array}{l}1.0467 * * * \\
(0.2118)\end{array}$ & $\begin{array}{l}0.5431 \\
(0.4974)\end{array}$ & $\begin{array}{l}0.9136 \text { *** } \\
(0.2311)\end{array}$ & $\begin{array}{l}0.4974 \\
(0.5249)\end{array}$ \\
\hline urb00 & $\begin{array}{l}1.6907 \text { *** } \\
(0.2429)\end{array}$ & $\begin{array}{l}1.0064 * \\
(0.5865)\end{array}$ & $\begin{array}{l}1.799 * * * \\
(0.2508)\end{array}$ & $\begin{array}{l}1.0539 * \\
(0.5983)\end{array}$ \\
\hline oth00 & $\begin{array}{l}1.7594 * * * \\
(0.2667)\end{array}$ & $\begin{array}{l}0.2513 \\
(0.4727)\end{array}$ & $\begin{array}{l}1.7154 \text { *** } \\
(0.2676)\end{array}$ & $\begin{array}{l}0.3347 \\
(0.468)\end{array}$ \\
\hline y2003 & $\begin{array}{c}0.0677 * \\
(0.0358)\end{array}$ & $\begin{array}{l}0.0709 \text { *** } \\
(0.0266)\end{array}$ & $\begin{array}{l}0.0696 \\
(0.0552)\end{array}$ & $\begin{array}{l}0.0754^{* *} \\
(0.0338)\end{array}$ \\
\hline $\begin{array}{l}\text { phi } \\
\text { rho }\end{array}$ & & $1.0162 * * *$ & & 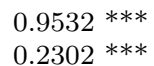 \\
\hline $\begin{array}{l}\text { rno } \\
\mathrm{N}\end{array}$ & 1586 & 1586 & $\begin{array}{l}0.3871 * * * \\
1586\end{array}$ & $\begin{array}{l}0.2302 * * * \\
1586\end{array}$ \\
\hline McFadden pseudo R2 & 0.195 & 0.646 & 0.249 & 0.667 \\
\hline McFadden pseudo R2 (adj.) & 0.175 & 0.626 & 0.228 & 0.646 \\
\hline Log. Lik. & -669.86 & -294.4 & -625.09 & -277.36 \\
\hline
\end{tabular}

Table 10: Models based on the triangulation neighborhood matrix 


\begin{tabular}{|c|c|c|c|c|}
\hline Variable & OLS & $\mathrm{RE}$ & SEM & SEM-RE \\
\hline (Intercept) & $\begin{array}{l}1.6902 * * * \\
(0.1528)\end{array}$ & $\begin{array}{l}1.8905 * * * \\
(0.2502)\end{array}$ & $\begin{array}{l}1.7285 * * * \\
(0.1612)\end{array}$ & $\begin{array}{l}1.94 * * * \\
(0.2623)\end{array}$ \\
\hline AgenceAG & $\begin{array}{l}0.1961 * * * \\
(0.0368)\end{array}$ & $\begin{array}{l}0.1598 * \\
(0.0871)\end{array}$ & $\begin{array}{l}0.1918 * * * \\
(0.0391)\end{array}$ & $\begin{array}{l}0.1576 * \\
(0.0939)\end{array}$ \\
\hline AgenceAP & $\begin{array}{l}0.0198 \\
(0.0543)\end{array}$ & $\begin{array}{l}0.0437 \\
(0.1307)\end{array}$ & $\begin{array}{l}0.0413 \\
(0.0605)\end{array}$ & $\begin{array}{l}0.0557 \\
(0.1466)\end{array}$ \\
\hline AgenceRM & $\begin{array}{l}0.1122 * * \\
(0.0497)\end{array}$ & $\begin{array}{l}0.1073 \\
(0.1217)\end{array}$ & $\begin{array}{l}0.1523 \text { *** } \\
(0.0521)\end{array}$ & $\begin{array}{l}0.1427 \\
(0.128)\end{array}$ \\
\hline AgenceRMC & $\begin{array}{l}0.4046 \text { *** } \\
(0.0424)\end{array}$ & $\begin{array}{l}0.3909 * * * \\
(0.1022)\end{array}$ & $\begin{array}{l}0.3937 * * * \\
(0.0448)\end{array}$ & $\begin{array}{l}0.3802 * * * \\
(0.1089)\end{array}$ \\
\hline AgenceSN & $\begin{array}{l}-0.2935 * * * \\
(0.0384)\end{array}$ & $\begin{array}{l}-0.2734 * * * \\
(0.0948)\end{array}$ & $\begin{array}{l}-0.268 * * * \\
(0.0404)\end{array}$ & $\begin{array}{l}-0.2432 * * \\
(0.1003)\end{array}$ \\
\hline Texture (cl. 2) & $\begin{array}{c}-0.0512 \\
(0.076)\end{array}$ & $\begin{array}{l}0.0774 \\
(0.1848)\end{array}$ & $\begin{array}{l}-0.024 \\
(0.0745)\end{array}$ & $\begin{array}{l}0.1129 \\
(0.1832)\end{array}$ \\
\hline Texture (cl. 3) & $\begin{array}{l}-0.1542 * * \\
(0.0764)\end{array}$ & $\begin{array}{l}-0.0696 \\
(0.1884)\end{array}$ & $\begin{array}{l}-0.1435 * \\
(0.0778)\end{array}$ & $\begin{array}{l}-0.068 \\
(0.1936)\end{array}$ \\
\hline Texture (cl. 4) & $\begin{array}{l}-0.0063 \\
(0.1135)\end{array}$ & $\begin{array}{l}0.129 \\
(0.2807)\end{array}$ & $\begin{array}{l}0.0119 \\
(0.1129)\end{array}$ & $\begin{array}{l}0.1462 \\
(0.282)\end{array}$ \\
\hline rain_cv & $\begin{array}{l}-0.0144 \\
(0.0415)\end{array}$ & $\begin{array}{l}-0.0014 \\
(0.0321)\end{array}$ & $\begin{array}{l}-0.0141 \\
(0.0473)\end{array}$ & $\begin{array}{l}-0.0012 \\
(0.0366)\end{array}$ \\
\hline $\mathrm{T}$ & $\begin{array}{l}-0.0023 \\
(0.0107)\end{array}$ & $\begin{array}{l}0.0086 \\
(0.0126)\end{array}$ & $\begin{array}{l}-0.005 \\
(0.0117)\end{array}$ & $\begin{array}{l}0.0043 \\
(0.0147)\end{array}$ \\
\hline $\operatorname{agr} 1$ & $\begin{array}{l}1.1388 * * * \\
(0.1827)\end{array}$ & $\begin{array}{l}0.8366 * * \\
(0.4098)\end{array}$ & $\begin{array}{l}1.1297 * * * \\
(0.1809)\end{array}$ & $\begin{array}{l}0.9149 * * \\
(0.4124)\end{array}$ \\
\hline $\operatorname{agr} 2$ & $\begin{array}{l}1.4614 \text { *** } \\
(0.1774)\end{array}$ & $\begin{array}{l}1.1449 * * * \\
(0.3971)\end{array}$ & $\begin{array}{l}1.5365 * * * \\
(0.1764)\end{array}$ & $\begin{array}{l}1.3052 \text { *** } \\
(0.4017)\end{array}$ \\
\hline agr3 & $\begin{array}{l}0.8215 * * * \\
(0.1571)\end{array}$ & $\begin{array}{l}0.2478 \\
(0.3438)\end{array}$ & $\begin{array}{l}0.8577 * * * \\
(0.158)\end{array}$ & $\begin{array}{l}0.2961 \\
(0.3513)\end{array}$ \\
\hline $\operatorname{agr} 4$ & $\begin{array}{l}1.0714 \text { *** } \\
(0.131)\end{array}$ & $\begin{array}{l}0.586 * * \\
(0.2891)\end{array}$ & $\begin{array}{l}0.9826 * * * \\
(0.1301)\end{array}$ & $\begin{array}{l}0.5151 * \\
(0.2929)\end{array}$ \\
\hline pst1 & $\begin{array}{l}0.5934 \\
(0.916)\end{array}$ & $\begin{array}{l}-1.1452 \\
(2.1058)\end{array}$ & $\begin{array}{l}0.1344 \\
(0.9282)\end{array}$ & $\begin{array}{l}-2.1728 \\
(2.1414)\end{array}$ \\
\hline pst2 & $\begin{array}{l}3.719 * * * \\
(0.3959)\end{array}$ & $\begin{array}{l}2.7871 \text { *** } \\
(0.9286)\end{array}$ & $\begin{array}{l}3.4522 \text { *** } \\
(0.41)\end{array}$ & $\begin{array}{l}2.3473 * * \\
(0.9689)\end{array}$ \\
\hline pst3 & $\begin{array}{l}2.7934 * * * \\
(0.2957)\end{array}$ & $\begin{array}{l}2.2973 \text { *** } \\
(0.6534)\end{array}$ & $\begin{array}{l}2.6781 * * * \\
(0.2979)\end{array}$ & $\begin{array}{l}2.2211 \text { *** } \\
(0.6732)\end{array}$ \\
\hline pst4 & $\begin{array}{l}1.9861 * * * \\
(0.2156)\end{array}$ & $\begin{array}{l}1.6212 \text { *** } \\
(0.4986)\end{array}$ & $\begin{array}{l}1.9021 * * * \\
(0.2239)\end{array}$ & $\begin{array}{l}1.5279 * * * \\
(0.5233)\end{array}$ \\
\hline urb00 & $\begin{array}{l}2.9445 * * * \\
(0.2567)\end{array}$ & $\begin{array}{l}2.2645 \text { *** } \\
(0.5941)\end{array}$ & $\begin{array}{l}2.7912 \text { *** } \\
(0.2611)\end{array}$ & $\begin{array}{l}2.0658 \text { *** } \\
(0.613)\end{array}$ \\
\hline oth00 & $\begin{array}{l}1.4824 \text { *** } \\
(0.2588)\end{array}$ & $\begin{array}{l}0.4097 \\
(0.4465)\end{array}$ & $\begin{array}{l}1.3751 * * * \\
(0.2603)\end{array}$ & $\begin{array}{l}0.3045 \\
(0.4508)\end{array}$ \\
\hline y2003 & $\begin{array}{l}0.0835 * * \\
(0.0339)\end{array}$ & $\begin{array}{l}0.0737 * * * \\
(0.0267)\end{array}$ & $\begin{array}{l}0.0861 \text { ** } \\
(0.0409)\end{array}$ & $\begin{array}{l}0.0778 * * \\
(0.0321)\end{array}$ \\
\hline phi & & $0.7605 * * *$ & & $0.7652 * * *$ \\
\hline rho & & & $0.1939 * * *$ & $0.1839 * * *$ \\
\hline $\mathrm{N}$ & 1586 & 1586 & 1586 & 1586 \\
\hline McFadden pseudo R2 & 0.319 & 0.664 & 0.335 & 0.682 \\
\hline McFadden pseudo R2 (adj.) & 0.293 & 0.638 & 0.309 & 0.656 \\
\hline Log. Lik. & -566.61 & -279.48 & -553.15 & -264.65 \\
\hline
\end{tabular}

Table 11: Models based on the contiguity neighborhood matrix, RBD fixed effects (LoireBretagne as reference) 


\begin{tabular}{|c|c|c|c|c|}
\hline Variable & OLS & $\mathrm{RE}$ & SEM & SEM-RE \\
\hline (Intercept) & $\begin{array}{l}1.6902 * * * \\
(0.1528)\end{array}$ & $\begin{array}{l}1.8905 * * * \\
(0.2502)\end{array}$ & $\begin{array}{l}1.7511 \text { *** } \\
(0.1611)\end{array}$ & $\begin{array}{l}1.9566 \text { *** } \\
(0.2626)\end{array}$ \\
\hline AgenceAG & $\begin{array}{l}0.1961 * * * \\
(0.0368)\end{array}$ & $\begin{array}{l}0.1598 * \\
(0.0871)\end{array}$ & $\begin{array}{l}0.198 * * * \\
(0.0397)\end{array}$ & $\begin{array}{l}0.1607 * \\
(0.0948)\end{array}$ \\
\hline AgenceAP & $\begin{array}{l}0.0198 \\
(0.0543)\end{array}$ & $\begin{array}{l}0.0437 \\
(0.1307)\end{array}$ & $\begin{array}{l}0.0401 \\
(0.0608)\end{array}$ & $\begin{array}{l}0.0539 \\
(0.1468)\end{array}$ \\
\hline AgenceRM & $\begin{array}{l}0.1122 * * \\
(0.0497)\end{array}$ & $\begin{array}{l}0.1073 \\
(0.1217)\end{array}$ & $\begin{array}{l}0.1629 * * * \\
(0.0526)\end{array}$ & $\begin{array}{l}0.1504 \\
(0.1288)\end{array}$ \\
\hline AgenceRMC & $\begin{array}{l}0.4046 * * * \\
(0.0424)\end{array}$ & $\begin{array}{l}0.3909 * * * \\
(0.1022)\end{array}$ & $\begin{array}{l}0.4002 \text { *** } \\
(0.0457)\end{array}$ & $\begin{array}{l}0.3847 * * * \\
(0.1106)\end{array}$ \\
\hline AgenceSN & $\begin{array}{l}-0.2935 * * * \\
(0.0384)\end{array}$ & $\begin{array}{l}-0.2734 * * * \\
(0.0948)\end{array}$ & $\begin{array}{l}-0.2669 \text { *** } \\
(0.0407)\end{array}$ & $\begin{array}{l}-0.2417^{* *} \\
(0.1009)\end{array}$ \\
\hline Texture (cl. 2) & $\begin{array}{l}-0.0512 \\
(0.076)\end{array}$ & $\begin{array}{l}0.0774 \\
(0.1848)\end{array}$ & $\begin{array}{l}-0.0271 \\
(0.0739)\end{array}$ & $\begin{array}{l}0.1129 \\
(0.1818)\end{array}$ \\
\hline Texture (cl. 3) & $\begin{array}{l}-0.1542^{* *} \\
(0.0764)\end{array}$ & $\begin{array}{l}-0.0696 \\
(0.1884)\end{array}$ & $\begin{array}{l}-0.1495 * \\
(0.078)\end{array}$ & $\begin{array}{l}-0.0711 \\
(0.1937)\end{array}$ \\
\hline Texture (cl. 4) & $\begin{array}{l}-0.0063 \\
(0.1135)\end{array}$ & $\begin{array}{l}0.129 \\
(0.2807)\end{array}$ & $\begin{array}{l}-0.0016 \\
(0.1122)\end{array}$ & $\begin{array}{l}0.1399 \\
(0.2801)\end{array}$ \\
\hline rain_cv & $\begin{array}{l}-0.0144 \\
(0.0415)\end{array}$ & $\begin{array}{l}-0.0014 \\
(0.0321)\end{array}$ & $\begin{array}{l}-0.0152 \\
(0.0478)\end{array}$ & $\begin{array}{l}-0.0032 \\
(0.0368)\end{array}$ \\
\hline $\mathrm{T}$ & $\begin{array}{l}-0.0023 \\
(0.0107)\end{array}$ & $\begin{array}{l}0.0086 \\
(0.0126)\end{array}$ & $\begin{array}{l}-0.0061 \\
(0.0118)\end{array}$ & $\begin{array}{l}0.0039 \\
(0.0148)\end{array}$ \\
\hline $\operatorname{agr} 1$ & $\begin{array}{l}1.1388 * * * \\
(0.1827)\end{array}$ & $\begin{array}{l}0.8366 * * \\
(0.4098)\end{array}$ & $\begin{array}{l}1.1076 \text { *** } \\
(0.1795)\end{array}$ & $\begin{array}{l}0.8956 \text { ** } \\
(0.4103)\end{array}$ \\
\hline $\operatorname{agr} 2$ & $\begin{array}{l}1.4614^{* * *} \\
(0.1774)\end{array}$ & $\begin{array}{l}1.1449 \text { *** } \\
(0.3971)\end{array}$ & $\begin{array}{l}1.5244 * * * \\
(0.176)\end{array}$ & $\begin{array}{l}1.293 * * * \\
(0.4014)\end{array}$ \\
\hline agr3 & $\begin{array}{l}0.8215 * * * \\
(0.1571)\end{array}$ & $\begin{array}{l}0.2478 \\
(0.3438)\end{array}$ & $\begin{array}{l}0.8571 * * * \\
(0.1585)\end{array}$ & $\begin{array}{l}0.2828 \\
(0.352)\end{array}$ \\
\hline $\operatorname{agr} 4$ & $\begin{array}{l}1.0714 \text { *** } \\
(0.131)\end{array}$ & $\begin{array}{l}0.586 * * \\
(0.2891)\end{array}$ & $\begin{array}{l}0.9825 * * * \\
(0.1304)\end{array}$ & $\begin{array}{l}0.5101 * \\
(0.2936)\end{array}$ \\
\hline pst1 & $\begin{array}{l}0.5934 \\
(0.916)\end{array}$ & $\begin{array}{l}-1.1452 \\
(2.1058)\end{array}$ & $\begin{array}{l}0.1952 \\
(0.929)\end{array}$ & $\begin{array}{l}-2.1582 \\
(2.1414)\end{array}$ \\
\hline pst2 & $\begin{array}{l}3.719 * * * \\
(0.3959)\end{array}$ & $\begin{array}{l}2.7871 \text { *** } \\
(0.9286)\end{array}$ & $\begin{array}{l}3.4851 * * * \\
(0.4109)\end{array}$ & $\begin{array}{l}2.362 * * \\
(0.969)\end{array}$ \\
\hline pst3 & $\begin{array}{l}2.7934 \text { *** } \\
(0.2957)\end{array}$ & $\begin{array}{l}2.2973 \text { *** } \\
(0.6534)\end{array}$ & $\begin{array}{l}2.5914 * * * \\
(0.2971)\end{array}$ & $\begin{array}{l}2.1452 \text { *** } \\
(0.6724)\end{array}$ \\
\hline pst4 & $\begin{array}{l}1.9861 \text { *** } \\
(0.2156)\end{array}$ & $\begin{array}{l}1.6212^{* * *} \\
(0.4986)\end{array}$ & $\begin{array}{l}1.8969 * * * \\
(0.224)\end{array}$ & $\begin{array}{l}1.5218 \text { *** } \\
(0.5233)\end{array}$ \\
\hline urb00 & $\begin{array}{l}2.9445 * * * \\
(0.2567)\end{array}$ & $\begin{array}{l}2.2645 * * * \\
(0.5941)\end{array}$ & $\begin{array}{l}2.7627 * * * \\
(0.2596)\end{array}$ & $\begin{array}{l}2.0245 \text { *** } \\
(0.6092)\end{array}$ \\
\hline oth00 & $\begin{array}{l}1.4824 * * * \\
(0.2588)\end{array}$ & $\begin{array}{l}0.4097 \\
(0.4465)\end{array}$ & $\begin{array}{l}1.3342^{* * *} \\
(0.2587)\end{array}$ & $\begin{array}{l}0.2718 \\
(0.4491)\end{array}$ \\
\hline y2003 & $\begin{array}{l}0.0835 * * \\
(0.0339)\end{array}$ & $\begin{array}{l}0.0737 * * * \\
(0.0267)\end{array}$ & $\begin{array}{l}0.0872 * * \\
(0.0417)\end{array}$ & $\begin{array}{l}0.0784 * * \\
(0.0324)\end{array}$ \\
\hline phi & & $0.7605 * * *$ & & $0.7643 * * *$ \\
\hline rho & & & $0.2109 * * *$ & $0.1927 * * *$ \\
\hline $\mathrm{N}$ & 1586 & 1586 & 1586 & 1586 \\
\hline McFadden pseudo R2 & 0.319 & 0.664 & 0.339 & 0.685 \\
\hline McFadden pseudo R2 (adj.) & 0.293 & 0.638 & 0.313 & 0.658 \\
\hline Log. Lik. & -566.61 & -279.48 & -549.99 & -262.25 \\
\hline
\end{tabular}

Table 12: Models based on the contiguity-upstream neighborhood matrix, RBD fixed effects (Loire-Bretagne as reference) 


\begin{tabular}{|c|c|c|c|c|}
\hline Variable & OLS & $\mathrm{RE}$ & SEM & SEM-RE \\
\hline (Intercept) & $\begin{array}{l}1.6902 * * * \\
(0.1528)\end{array}$ & $\begin{array}{l}1.8905 * * * \\
(0.2502)\end{array}$ & $\begin{array}{l}1.7733 \text { *** } \\
(0.1638)\end{array}$ & $\begin{array}{l}1.9776 \text { *** } \\
(0.2628)\end{array}$ \\
\hline AgenceAG & $\begin{array}{l}0.1961 * * * \\
(0.0368)\end{array}$ & $\begin{array}{l}0.1598 * \\
(0.0871)\end{array}$ & $\begin{array}{l}0.1789 * * * \\
(0.0396)\end{array}$ & $\begin{array}{l}0.1447 \\
(0.0938)\end{array}$ \\
\hline AgenceAP & $\begin{array}{l}0.0198 \\
(0.0543)\end{array}$ & $\begin{array}{l}0.0437 \\
(0.1307)\end{array}$ & $\begin{array}{l}0.0372 \\
(0.0605)\end{array}$ & $\begin{array}{l}0.0491 \\
(0.1448)\end{array}$ \\
\hline AgenceRM & $\begin{array}{l}0.1122 * * \\
(0.0497)\end{array}$ & $\begin{array}{l}0.1073 \\
(0.1217)\end{array}$ & $\begin{array}{l}0.1151 * * \\
(0.0524)\end{array}$ & $\begin{array}{l}0.1022 \\
(0.1276)\end{array}$ \\
\hline AgenceRMC & $\begin{array}{l}0.4046 \text { *** } \\
(0.0424)\end{array}$ & $\begin{array}{l}0.3909 * * * \\
(0.1022)\end{array}$ & $\begin{array}{l}0.3729 * * * \\
(0.0453)\end{array}$ & $\begin{array}{l}0.3604 * * * \\
(0.1086)\end{array}$ \\
\hline AgenceSN & $\begin{array}{l}-0.2935 * * * \\
(0.0384)\end{array}$ & $\begin{array}{l}-0.2734 \\
(0.0948)\end{array}$ & $\begin{array}{l}-0.2823 * * * \\
(0.0407)\end{array}$ & $\begin{array}{l}-0.2608 \text { *** } \\
(0.1001)\end{array}$ \\
\hline Texture (cl. 2) & $\begin{array}{c}-0.0512 \\
(0.076)\end{array}$ & $\begin{array}{l}0.0774 \\
(0.1848)\end{array}$ & $\begin{array}{l}-0.047 \\
(0.0754)\end{array}$ & $\begin{array}{l}0.0832 \\
(0.1845)\end{array}$ \\
\hline Texture (cl. 3) & $\begin{array}{l}-0.1542 * * \\
(0.0764)\end{array}$ & $\begin{array}{l}-0.0696 \\
(0.1884)\end{array}$ & $\begin{array}{l}-0.1291 \\
(0.0786)\end{array}$ & $\begin{array}{l}-0.0598 \\
(0.1937)\end{array}$ \\
\hline Texture (cl. 4) & $\begin{array}{l}-0.0063 \\
(0.1135)\end{array}$ & $\begin{array}{l}0.129 \\
(0.2807)\end{array}$ & $\begin{array}{l}-0.0191 \\
(0.1129)\end{array}$ & $\begin{array}{l}0.1244 \\
(0.2801)\end{array}$ \\
\hline rain_cv & $\begin{array}{l}-0.0144 \\
(0.0415)\end{array}$ & $\begin{array}{l}-0.0014 \\
(0.0321)\end{array}$ & $\begin{array}{l}-0.0159 \\
(0.0482)\end{array}$ & $\begin{array}{l}0.0013 \\
(0.037)\end{array}$ \\
\hline $\mathrm{T}$ & $\begin{array}{l}-0.0023 \\
(0.0107)\end{array}$ & $\begin{array}{l}0.0086 \\
(0.0126)\end{array}$ & $\begin{array}{l}-0.0039 \\
(0.0119)\end{array}$ & $\begin{array}{l}0.0036 \\
(0.015)\end{array}$ \\
\hline $\operatorname{agr} 1$ & $\begin{array}{l}1.1388 * * * \\
(0.1827)\end{array}$ & $\begin{array}{l}0.8366 * * \\
(0.4098)\end{array}$ & $\begin{array}{l}1.063 * * * \\
(0.1819)\end{array}$ & $\begin{array}{l}0.8622 * * \\
(0.4138)\end{array}$ \\
\hline $\operatorname{agr} 2$ & $\begin{array}{l}1.4614 \text { *** } \\
(0.1774)\end{array}$ & $\begin{array}{l}1.1449 * * * \\
(0.3971)\end{array}$ & $\begin{array}{l}1.3426 \text { *** } \\
(0.1753)\end{array}$ & $\begin{array}{l}1.147^{* * *} \\
(0.3987)\end{array}$ \\
\hline $\operatorname{agr} 3$ & $\begin{array}{l}0.8215 * * * \\
(0.1571)\end{array}$ & $\begin{array}{l}0.2478 \\
(0.3438)\end{array}$ & $\begin{array}{l}0.8159 * * * \\
(0.1587)\end{array}$ & $\begin{array}{l}0.2913 \\
(0.3525)\end{array}$ \\
\hline $\operatorname{agr} 4$ & $\begin{array}{l}1.0714 \text { *** } \\
(0.131)\end{array}$ & $\begin{array}{l}0.586 * * \\
(0.2891)\end{array}$ & $\begin{array}{l}0.9973 * * * \\
(0.1303)\end{array}$ & $\begin{array}{l}0.5616^{*} \\
(0.293)\end{array}$ \\
\hline pst1 & $\begin{array}{l}0.5934 \\
(0.916)\end{array}$ & $\begin{array}{l}-1.1452 \\
(2.1058)\end{array}$ & $\begin{array}{l}0.7642 \\
(0.9058)\end{array}$ & $\begin{array}{l}-1.4384 \\
(2.1006)\end{array}$ \\
\hline pst2 & $\begin{array}{l}3.719 * * * \\
(0.3959)\end{array}$ & $\begin{array}{l}2.7871 * * * \\
(0.9286)\end{array}$ & $\begin{array}{l}3.7656 \text { *** } \\
(0.4044)\end{array}$ & $\begin{array}{l}2.6632 \text { *** } \\
(0.952)\end{array}$ \\
\hline pst3 & $\begin{array}{l}2.7934 \text { *** } \\
(0.2957)\end{array}$ & $\begin{array}{l}2.2973 \text { *** } \\
(0.6534)\end{array}$ & $\begin{array}{l}2.4554 * * * \\
(0.3004)\end{array}$ & $\begin{array}{l}2.0268 * * * \\
(0.6726)\end{array}$ \\
\hline pst4 & $\begin{array}{l}1.9861 \text { *** } \\
(0.2156)\end{array}$ & $\begin{array}{l}1.6212 * * * \\
(0.4986)\end{array}$ & $\begin{array}{l}1.7912 \text { *** } \\
(0.2267)\end{array}$ & $\begin{array}{l}1.461 * * * \\
(0.5265)\end{array}$ \\
\hline urb00 & $\begin{array}{l}2.9445 * * * \\
(0.2567)\end{array}$ & $\begin{array}{l}2.2645 * * * \\
(0.5941)\end{array}$ & $\begin{array}{l}2.7822 \text { *** } \\
(0.2595)\end{array}$ & $\begin{array}{l}2.1016 \text { *** } \\
(0.6057)\end{array}$ \\
\hline oth00 & $\begin{array}{l}1.4824 * * * \\
(0.2588)\end{array}$ & $\begin{array}{l}0.4097 \\
(0.4465)\end{array}$ & $\begin{array}{l}1.4431 * * * \\
(0.2627)\end{array}$ & $\begin{array}{l}0.4369 \\
(0.4474)\end{array}$ \\
\hline y2003 & $\begin{array}{l}0.0835 * * \\
(0.0339)\end{array}$ & $\begin{array}{l}0.0737 * * * \\
(0.0267)\end{array}$ & $\begin{array}{l}0.0866 \text { ** } \\
(0.0431)\end{array}$ & $\begin{array}{l}0.0792 * * \\
(0.0331)\end{array}$ \\
\hline phi & & $0.7605 * * *$ & & $0.7524 * * *$ \\
\hline rho & & & $0.2381 * * *$ & $0.209 * * *$ \\
\hline $\mathrm{N}$ & 1586 & 1586 & 1586 & 1586 \\
\hline McFadden pseudo R2 & 0.319 & 0.664 & 0.338 & 0.681 \\
\hline McFadden pseudo R2 (adj.) & 0.293 & 0.638 & 0.312 & 0.654 \\
\hline Log. Lik. & -566.61 & -279.48 & -550.59 & -265.64 \\
\hline
\end{tabular}

Table 13: Models based on the triangulation neighborhood matrix, RBD fixed effects (Loire-Bretagne as reference) 
Land use shares are aggregated following the rules provided in Table 14. The data used for the land use model (Equation 5 is summarized in Table 15 Table 16 presents the estimated coefficients of the model.

\begin{tabular}{lrr}
\hline Land Cover class & CLC value & LU class \\
\hline 1 Artificial Surfaces & $1, \ldots, 11$ & Urban \\
2 Agricultural Areas & $12, \ldots, 22$ & Agriculture \\
3.1 Forests & $23, \ldots, 25$ & Forest \\
3.2 Shrub and/or herbaceous vegetation associations & $26, \ldots, 29$ & Other \\
3.3 Open spaces with little or no vegetation & $30, \ldots, 34$ & Other \\
4 Wetlands & $35, \ldots, 39$ & Other \\
5 Water bodies & $40, \ldots, 44$ & Other \\
\hline
\end{tabular}

Table 14: Extract from the CLC classification and the corresponding LU aggregation 


\begin{tabular}{|c|c|c|c|c|c|}
\hline Variable & Description & Mean & St. dev. & Min & $\operatorname{Max}$ \\
\hline \multicolumn{6}{|l|}{ Land use } \\
\hline$s_{a g}$ & Share of crops and pastures & 0.601 & 0.289 & 0 & 1 \\
\hline$s_{f o}$ & Share of forest & 0.264 & 0.225 & 0 & 1 \\
\hline$s_{u r}$ & Share of urban & 0.049 & 0.093 & 0 & 1 \\
\hline \multirow[t]{3}{*}{$s_{o t}$} & Share of other uses & 0.086 & 0.173 & 0 & 1 \\
\hline & Source: CLC 2000 & & & & \\
\hline & Scale: aggregated at $8 \mathrm{~km} \times 8 \mathrm{~km}$ & & & & \\
\hline \multirow[t]{3}{*}{ Shadow price } & Land shadow price $(\mathrm{k} € / \mathrm{ha})$ & 0.554 & 0.218 & 0 & 1.11 \\
\hline & Source: AROPAj v.2 (2002) & & & & \\
\hline & Scale: NUTS 2 and lower & & & & \\
\hline \multirow[t]{3}{*}{ For revenue } & Forestry revenues $(€ /$ ha $)$ & 137.683 & 66.509 & 28.934 & 308.043 \\
\hline & Source: FFSM++, 2006 & & & & \\
\hline & Scale: NUTS 2 scale & & & & \\
\hline \multirow[t]{4}{*}{ Pop revenues } & Households' revenues ( $\mathrm{k} € /$ year/ house- & 12.308 & 3.239 & 0 & 41.802 \\
\hline & hold) & & & & \\
\hline & Source: INSEE, 2000 & & & & \\
\hline & Scale: French commune & & & & \\
\hline \multirow[t]{3}{*}{ Pop density } & Households density (households/ ha) & 5.432 & 2.274 & 2.75 & 58.722 \\
\hline & Source: INSEE, 2000 & & & & \\
\hline & Scale: $200 \mathrm{~m} \times 200 \mathrm{~m}$ grid & & & & \\
\hline \multirow[t]{3}{*}{ Slope } & Slope $(\%)$ & 4.325 & 6.155 & 0 & 47.721 \\
\hline & Source: GTOPO 30 & & & & \\
\hline & Scale: 30 arc sec $\sim 1 \mathrm{~km}$ & & & & \\
\hline \multirow[t]{4}{*}{ Texture } & Soils' texture classes & 1 & 2 & 3 & 4 \\
\hline & Number of cells & 1242 & 4820 & 3120 & 579 \\
\hline & Source: JRC, Panagos et al. (2012) & & & & \\
\hline & Scale: 1:1000000 & & & & \\
\hline
\end{tabular}

Table 15: Summary statistics of land use shares and the explanatory variables 


\begin{tabular}{|c|c|c|c|}
\hline & \multicolumn{3}{|c|}{ Dependent variable: } \\
\hline & $\begin{array}{c}\ln (\text { agr } / \text { oth }) \\
(1)\end{array}$ & $\begin{array}{c}\ln (\text { for } / \text { oth }) \\
(2)\end{array}$ & $\begin{array}{c}\ln (\text { urb/oth }) \\
(3)\end{array}$ \\
\hline Constant & $\begin{array}{c}2.644^{* * *} \\
(0.618)\end{array}$ & $\begin{array}{c}3.151^{* * *} \\
(0.599)\end{array}$ & $\begin{array}{c}-6.376^{* * *} \\
(0.551)\end{array}$ \\
\hline Shadow price (spat) & $\begin{array}{c}0.888^{* * *} \\
(0.303)\end{array}$ & $\begin{array}{l}-0.406 \\
(0.303)\end{array}$ & $\begin{array}{l}0.568^{*} \\
(0.304)\end{array}$ \\
\hline For. revenues & $\begin{array}{c}0.003^{* * *} \\
(0.001)\end{array}$ & $\begin{array}{c}0.003^{* * *} \\
(0.001)\end{array}$ & $\begin{array}{c}0.004^{* * *} \\
(0.001)\end{array}$ \\
\hline Pop. density & $\begin{array}{c}-0.131^{* * *} \\
(0.013)\end{array}$ & $\begin{array}{c}-0.145^{* * *} \\
(0.014)\end{array}$ & $\begin{array}{c}0.168^{* * *} \\
(0.015)\end{array}$ \\
\hline Pop. Revenues & $\begin{array}{c}0.047^{* * *} \\
(0.014)\end{array}$ & $\begin{array}{c}0.062^{* * *} \\
(0.014)\end{array}$ & $\begin{array}{c}0.236^{* * *} \\
(0.016)\end{array}$ \\
\hline Slope & $\begin{array}{c}-0.154^{* * *} \\
(0.012)\end{array}$ & $\begin{array}{l}0.027^{* *} \\
(0.013)\end{array}$ & $\begin{array}{c}-0.153^{* * *} \\
(0.014)\end{array}$ \\
\hline Texture (cl.2) & $\begin{array}{c}0.668^{* * *} \\
(0.098)\end{array}$ & $\begin{array}{c}0.314^{* * *} \\
(0.100)\end{array}$ & $\begin{array}{c}0.509^{* * *} \\
(0.111)\end{array}$ \\
\hline TXT2 Texture (cl.3) & $\begin{array}{c}1.186^{* * *} \\
(0.115)\end{array}$ & $\begin{array}{c}0.672^{* * *} \\
(0.118)\end{array}$ & $\begin{array}{c}0.896^{* * *} \\
(0.129)\end{array}$ \\
\hline Texture (cl.4) & $\begin{array}{c}1.780^{* * *} \\
(0.159)\end{array}$ & $\begin{array}{c}0.980^{* * *} \\
(0.163)\end{array}$ & $\begin{array}{c}0.920^{* * *} \\
(0.180)\end{array}$ \\
\hline Shadow price (W2) & $\begin{array}{l}1.542^{*} \\
(0.841)\end{array}$ & $\begin{array}{l}-0.645 \\
(0.820)\end{array}$ & $\begin{array}{c}0.837 \\
(0.765)\end{array}$ \\
\hline For. revenues (W2) & $\begin{array}{c}0.011^{* * *} \\
(0.002)\end{array}$ & $\begin{array}{c}0.008^{* * *} \\
(0.002)\end{array}$ & $\begin{array}{c}0.011^{* * *} \\
(0.002)\end{array}$ \\
\hline Pop. density (W1) & $\begin{array}{c}-0.239^{* * *} \\
(0.035)\end{array}$ & $\begin{array}{c}-0.215^{* * *} \\
(0.036)\end{array}$ & $\begin{array}{c}-0.165^{* * *} \\
(0.037)\end{array}$ \\
\hline Pop. Revenues (W1) & $\begin{array}{l}-0.011 \\
(0.029)\end{array}$ & $\begin{array}{l}-0.029 \\
(0.029)\end{array}$ & $\begin{array}{c}0.096^{* * *} \\
(0.029)\end{array}$ \\
\hline Slope (W1) & $\begin{array}{c}-0.138^{* * *} \\
(0.019)\end{array}$ & $\begin{array}{c}-0.118^{* * *} \\
(0.019)\end{array}$ & $\begin{array}{c}-0.098^{* * *} \\
(0.019)\end{array}$ \\
\hline Texture (cl.2, W1) & $\begin{array}{c}0.112 \\
(0.096)\end{array}$ & $\begin{array}{l}0.210^{* *} \\
(0.098)\end{array}$ & $\begin{array}{c}0.341^{* * *} \\
(0.106)\end{array}$ \\
\hline Texture (cl.3, W1) & $\begin{array}{c}0.132 \\
(0.094)\end{array}$ & $\begin{array}{l}0.246^{* *} \\
(0.095)\end{array}$ & $\begin{array}{l}0.201^{* *} \\
(0.103)\end{array}$ \\
\hline Texture (cl.4, W1) & $\begin{array}{l}0.245^{* *} \\
(0.105)\end{array}$ & $\begin{array}{c}0.083 \\
(0.107)\end{array}$ & $\begin{array}{l}0.194^{*} \\
(0.115)\end{array}$ \\
\hline$N$ & 9761 & & \\
\hline $\mathrm{R} 2$ & 0.635 & 0.443 & 0.558 \\
\hline Moran's $I$ & $0.438^{* * *}$ & $0.402^{* * *}$ & $0.343^{* * *}$ \\
\hline$\lambda$ & $0.759^{* * *}$ & $0.738^{* * *}$ & $0.658^{* * *}$ \\
\hline Log Lik. & -22128.97 & -22391.3 & -23449.36 \\
\hline $\mathrm{AIC}$ & 44295.95 & 44820.61 & 46936.71 \\
\hline (AIC for LM) & 48524.05 & 48493.73 & 49569.55 \\
\hline
\end{tabular}

Table 16: SDEM estimates for the land use model 


\section{E Simulations scenarios: water quality and prediction in-} tervals

Figures 7, 8 and 9 represent the number of hydrographic sectors in each water quality class and for each climate change and policy scenario. The water quality class for each sector is assigned given the estimated FBI index value for the sector. The latter estimates are subject to prediction errors and for this reason we have also provided the distribution of the predictions in each water quality class (second column in figures 7, 8 and 9). For instance, in the "Status quo" case under current climate presented in the top row of figure 7. there are ten sectors that are classified as being in water quality class "Bad" which represent $5.56 \%$ of all sectors (table on the left in the top row). The predicted intervals for the FBI index for these ten sectors are represented on the right. We can see that in this case there are two sectors that have an important part of their prediction distributions below the threshold value of 25 . There is also one sector that overlaps with the "Very bad" class (values above 36 ). 


\begin{tabular}{rll}
\multicolumn{2}{l}{ Status quo } \\
\hline & Count & Share \\
\hline Very bad & 1 & $0.56 \%$ \\
Bad & 10 & $5.56 \%$ \\
Mediocre & 86 & $47.78 \%$ \\
Good & 82 & $45.56 \%$ \\
Very good & 1 & $0.56 \%$ \\
\hline
\end{tabular}
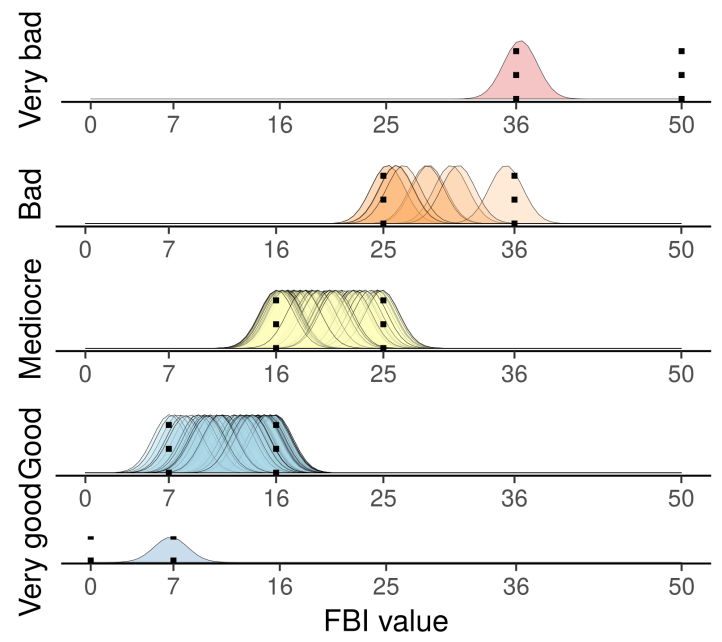

\begin{tabular}{rll}
\multicolumn{3}{l}{ Pasture policy } \\
\hline & Count & Share \\
\hline Very bad & 0 & $0 \%$ \\
Bad & 4 & $2.22 \%$ \\
Mediocre & 86 & $47.78 \%$ \\
Good & 89 & $49.44 \%$ \\
Very good & 1 & $0.56 \%$ \\
\hline
\end{tabular}
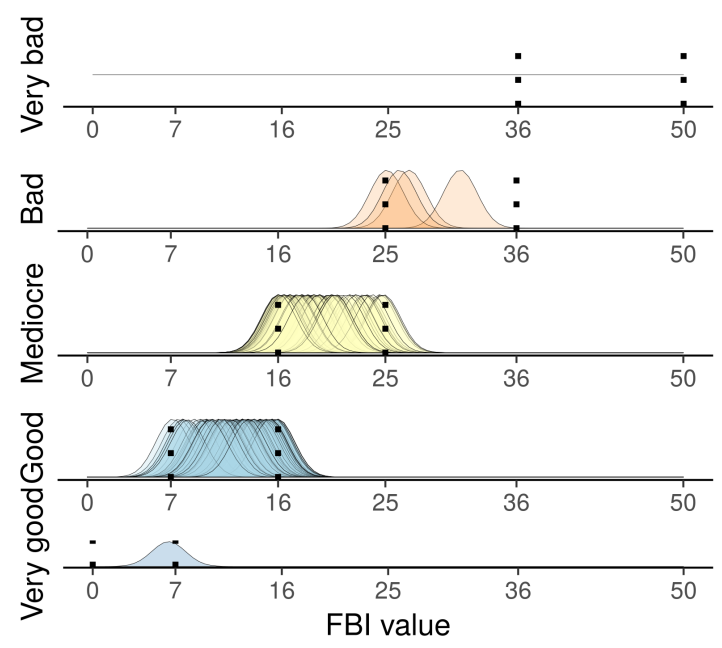

\begin{tabular}{rll}
\multicolumn{3}{l}{ Agricultural policy } \\
\hline & Count & Share \\
\hline Very bad & 0 & $0 \%$ \\
Bad & 3 & $1.67 \%$ \\
Mediocre & 69 & $38.33 \%$ \\
Good & 106 & $58.89 \%$ \\
Very good & 2 & $1.11 \%$ \\
\hline
\end{tabular}
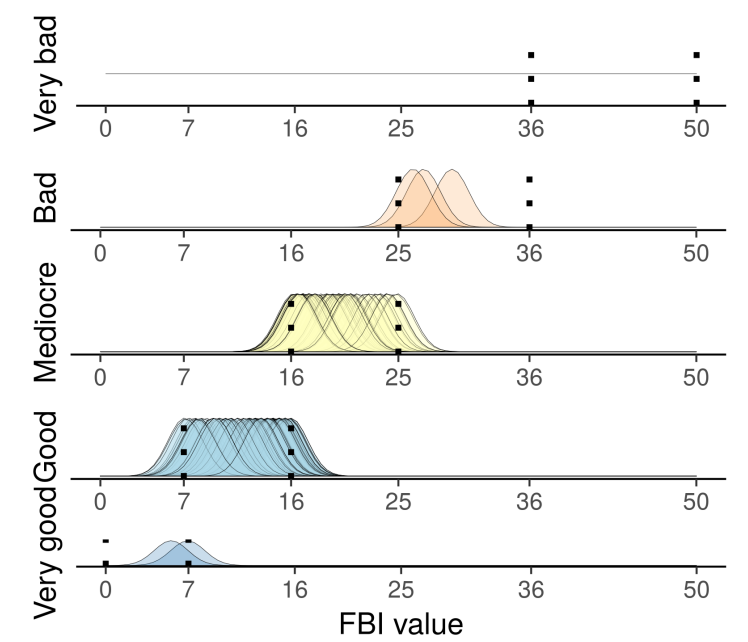

Water quality classes: "Very good" (FBI $\leq 7)$; "Good" (FBI $\in$ ]7-16]);

"Mediocre" (FBI $\in$ ]16-25]); "Bad" (FBI $\in$ ]25-36]); "Very bad" (FBI >36).

Figure 7: Summary results for water quality classes (first column) and FBI indexes' prediction intervals dsecond column $)_{c}$ under current climate and for the two land use 


\begin{tabular}{rll}
\multicolumn{2}{l}{ B1, Status quo } \\
\hline & Count & Share \\
\hline Very bad & 2 & $1.1 \%$ \\
Bad & 19 & $10.5 \%$ \\
Mediocre & 83 & $45.86 \%$ \\
Good & 77 & $42.54 \%$ \\
Very good & 0 & $0 \%$ \\
\hline
\end{tabular}
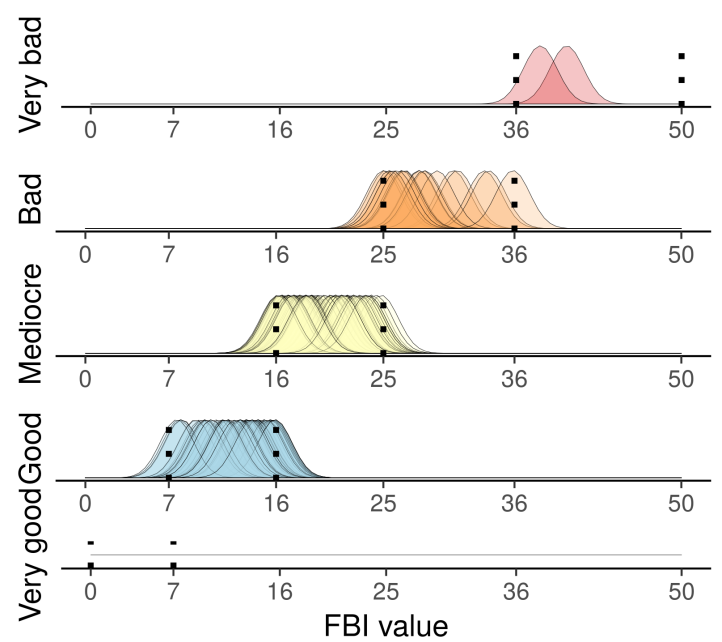

B1, Pasture policy

\begin{tabular}{rll}
\hline & Count & Share \\
\hline Very bad & 0 & $0 \%$ \\
Bad & 11 & $6.08 \%$ \\
Mediocre & 88 & $48.62 \%$ \\
Good & 82 & $45.3 \%$ \\
Very good & 0 & $0 \%$ \\
\hline
\end{tabular}
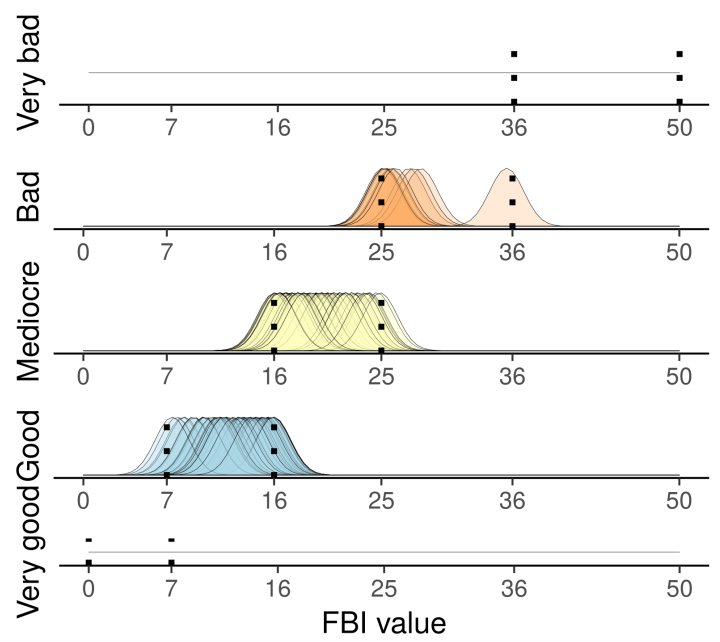

\section{B1, Agricultural policy}

\begin{tabular}{rll}
\hline & Count & Share \\
\hline Very bad & 0 & $0 \%$ \\
Bad & 7 & $3.87 \%$ \\
Mediocre & 72 & $39.78 \%$ \\
Good & 101 & $55.8 \%$ \\
Very good & 1 & $0.55 \%$ \\
\hline
\end{tabular}
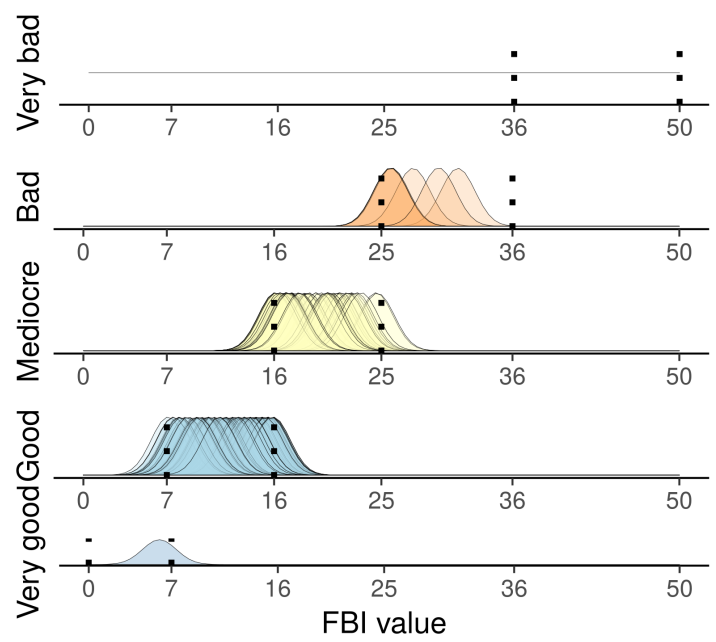

Water quality classes: "Very good" (FBI $\leq 7)$; "Good" (FBI $\in$ ]7-16]);

"Mediocre" (FBI $\in$ ]16-25]); "Bad" (FBI $\in$ ]25-36]); "Very bad" (FBI >36).

Figure 8: Summary results for water quality classes (first column) and FBI indexes' prediction intervals (second column) dunder $\mathrm{B} 1$ climate scenario and for the two land use 


\begin{tabular}{rll}
\multicolumn{2}{c}{ A2, Status quo } \\
\hline & Count & Share \\
\hline Very bad & 2 & $1.1 \%$ \\
Bad & 21 & $11.6 \%$ \\
Mediocre & 88 & $48.62 \%$ \\
Good & 70 & $38.67 \%$ \\
Very good & 0 & $0 \%$ \\
\hline
\end{tabular}
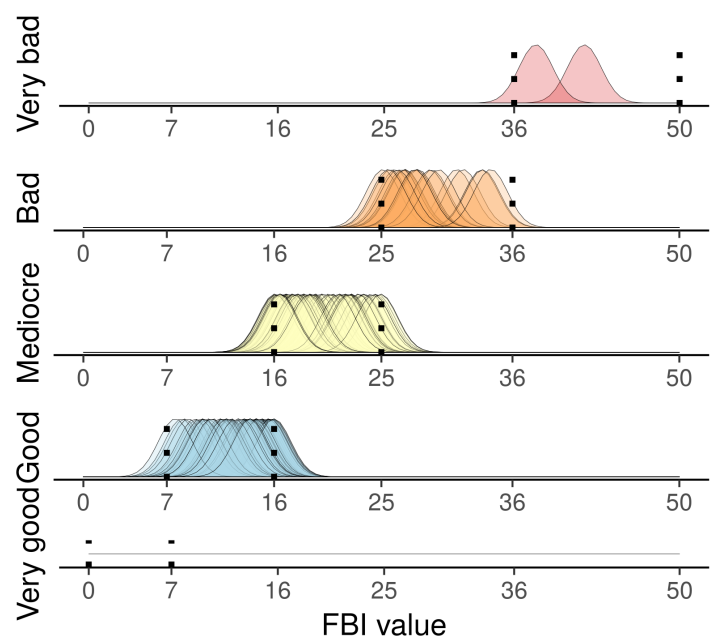

\begin{tabular}{rll} 
A2, Pasture policy & \\
\hline & Count & Share \\
\hline Very bad & 0 & $0 \%$ \\
Bad & 12 & $6.63 \%$ \\
Mediocre & 93 & $51.38 \%$ \\
Good & 76 & $41.99 \%$ \\
Very good & 0 & $0 \%$ \\
\hline
\end{tabular}
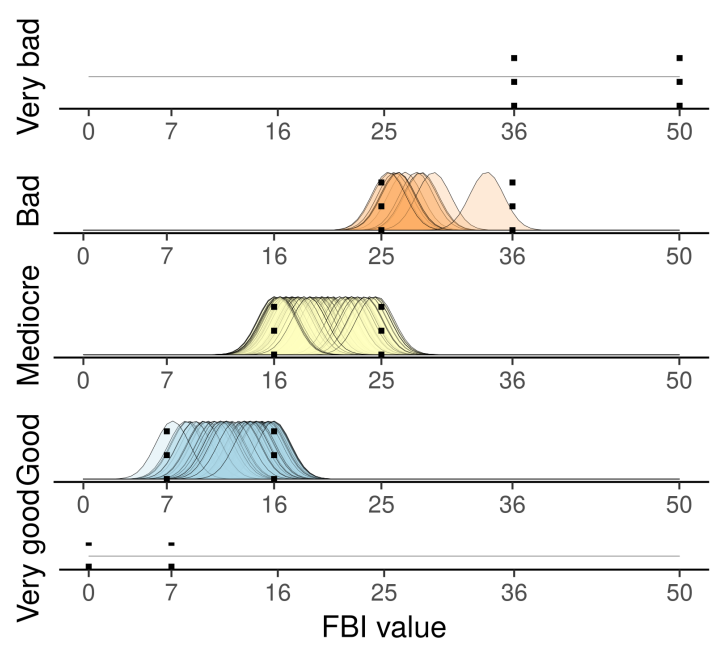

\section{A2, Agricultural policy}

\begin{tabular}{rll}
\hline & Count & Share \\
\hline Very bad & 0 & $0 \%$ \\
Bad & 8 & $4.42 \%$ \\
Mediocre & 81 & $44.75 \%$ \\
Good & 91 & $50.28 \%$ \\
Very good & 1 & $0.55 \%$ \\
\hline
\end{tabular}
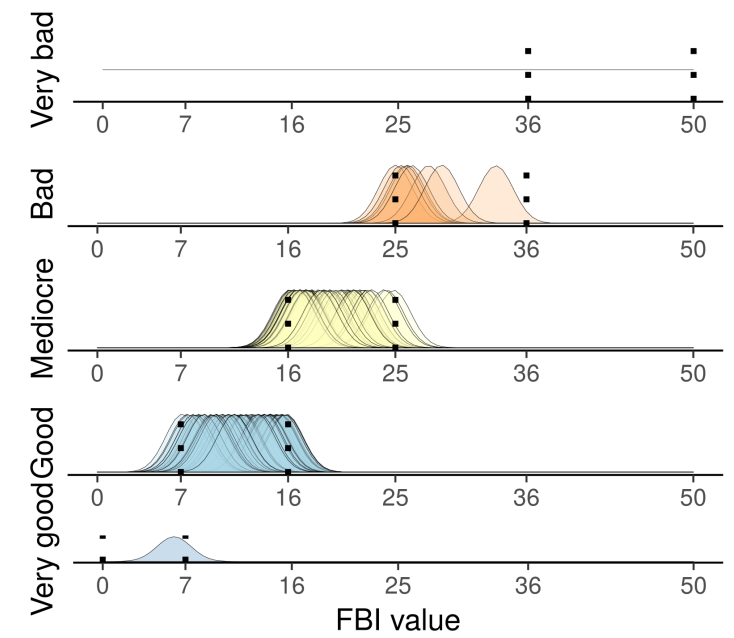

Water quality classes: "Very good" (FBI $\leq 7)$; "Good" (FBI $\in$ ]7-16]);

"Mediocre" (FBI $\in$ ]16-25]); "Bad" (FBI $\in$ ]25-36]); "Very bad" (FBI >36).

Figure 9: Summary results for water quality classes (first column) and FBI indexes' prediction intervals (second column) dunder $\mathrm{A} 2$ climate scenario and for the two land use 